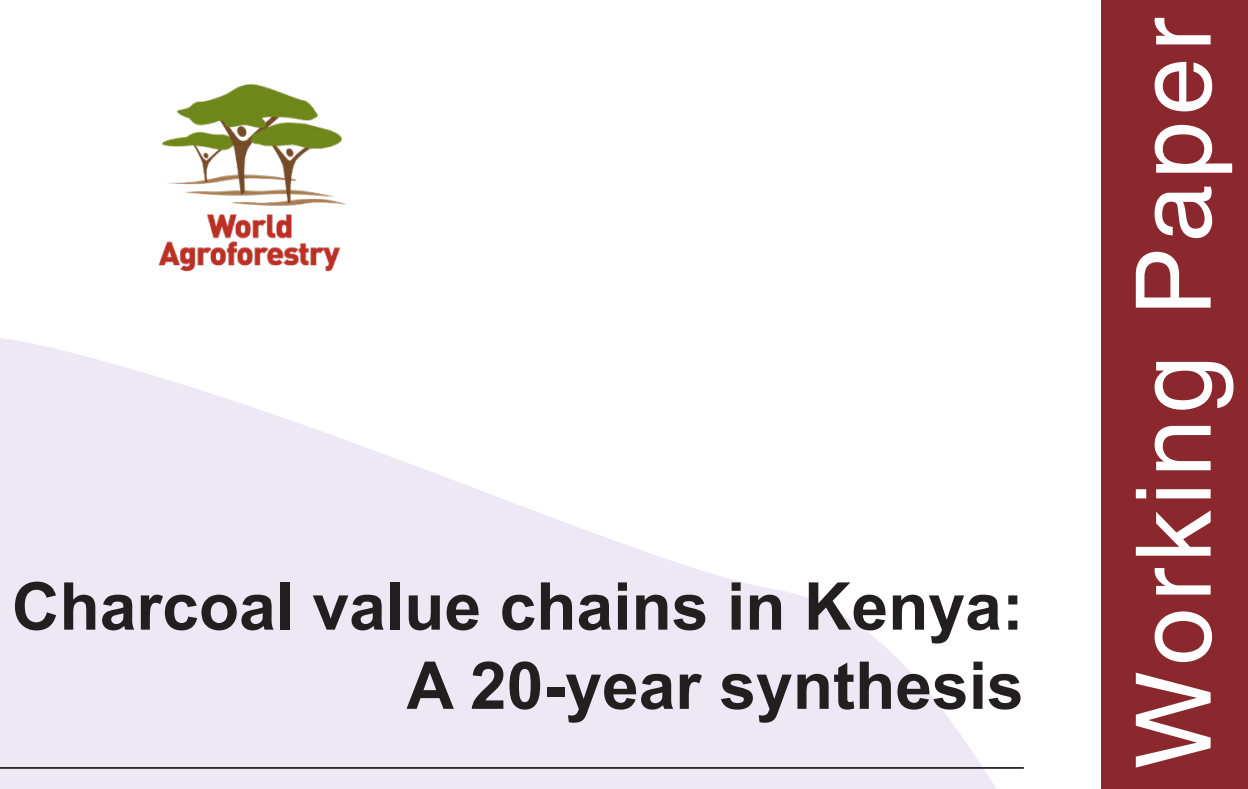

Geoffrey Ndegwa, Phosiso Sola, Miyuki liyama, Irene Okeyo, Mary Njenga, Ignatius Siko, Jonathan Muriuki

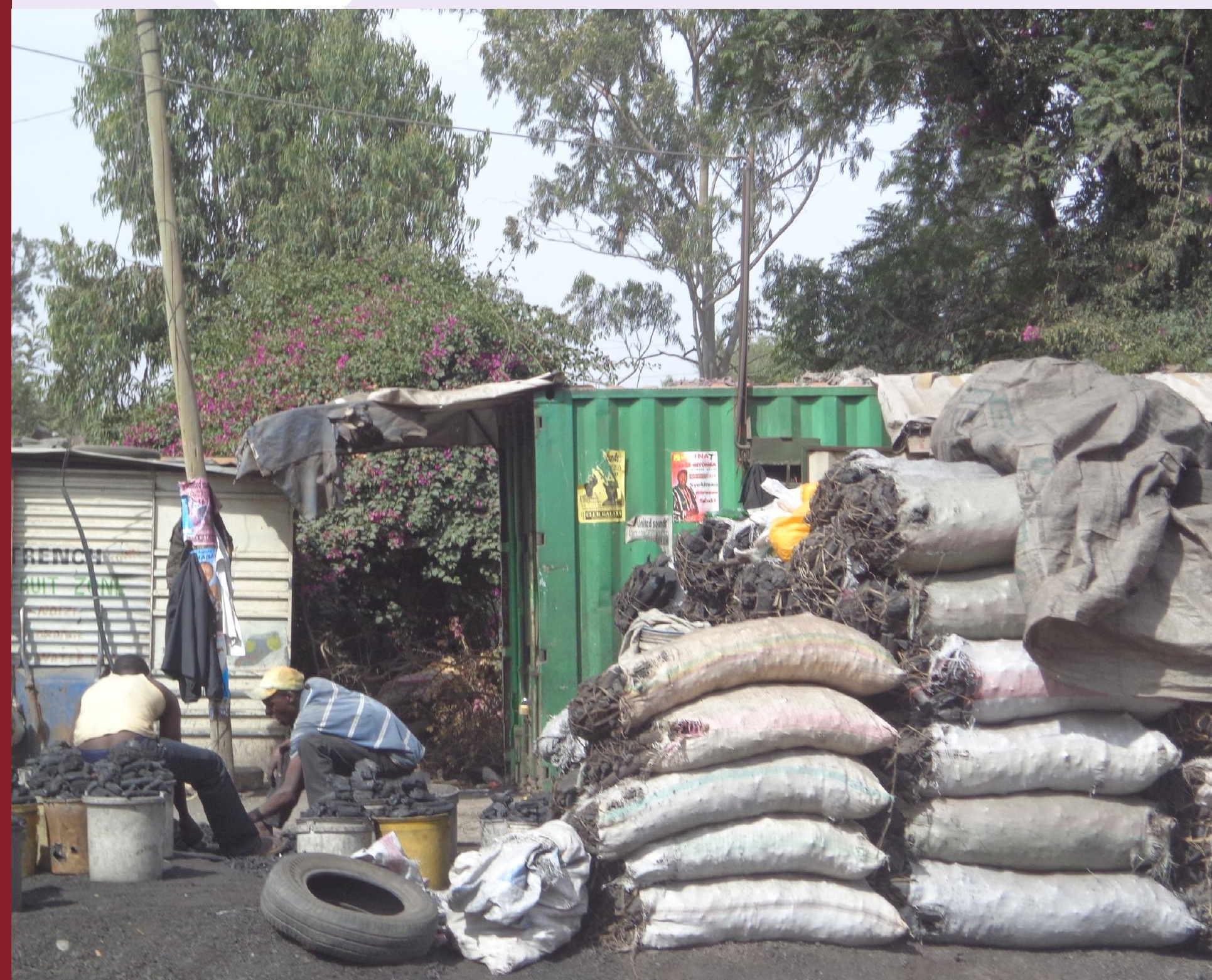




\section{Charcoal value chains in Kenya: a 20-year synthesis}

Geoffrey Ndegwa, Phosiso Sola, Miyuki liyama, Irene Okeyo, Mary Njenga, Ignatius Siko, Jonathan Muriuki

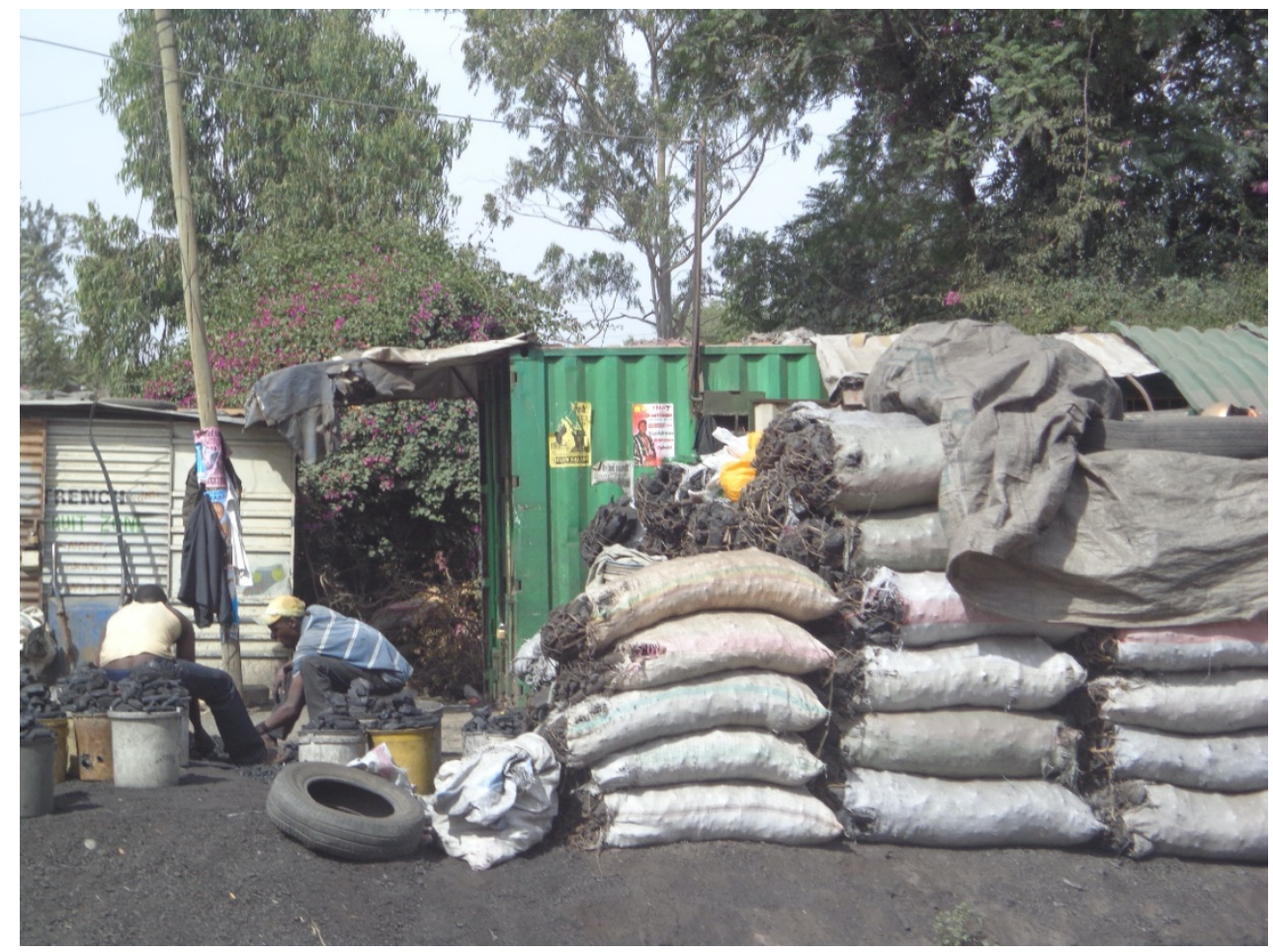


Correct citation: Ndegwa G, Sola, P., liyama M, Okeyo I, Njenga M, Siko I., Muriuki, J.2020. Charcoal value chains in Kenya: a 20-year synthesis. Working Paper number 307. World Agroforestry, Nairobi, Kenya. DOI http://dx.doi.org/10.5716/WP20026.PDF

The titles of the Working Paper Series are intended to disseminate provisional results of agroforestry research and practices and to stimulate feedback from the scientific community. Other World Agroforestry publication series include Technical Manuals, Occasional Papers and the Trees for Change Series.

Published by World Agroforestry (ICRAF)

PO Box 30677, GPO 00100

Nairobi, Kenya

Tel: +254(0)20 7224000, via USA +16508336645

Fax: +254(0)20 7224001, via USA +1 6508336646

Email: worldagroforestry@cgiar.org

Website: www.worldagroforestry.org

(C) World Agroforestry 2020

Working Paper No. 307

Front cover photo: Charcoal retail in Nairobi. By Miyuki liyama

The views expressed in this publication are those of the authors and not necessarily those of World Agroforestry.

Articles appearing in this publication may be quoted or reproduced without charge, provided the source is acknowledged.

All images remain the sole property of their source and may not be used for any purpose without written permission of the source. 


\section{About the Authors}

Geoffrey Ndegwa is an independent consultant who specializes in the field of renewable energy, environment and natural resource management. He is currently engaged by the Norwegian Capacity (NORCAP) as an Energy and Environment expert to support UN organizations in sustainable energy programming in displacement settings. He has over 10 years of experience working/consulting, teaching and conducting research in the fields of renewable energy, forestry, environment, climate change and natural resource management. He holds a PhD in Geography, focusing on Environment and Natural Resource Management from the University of Passau in Germany. Email: gefmaina@yahoo.com

Phosiso Sola* is a scientist at World Agroforestry (ICRAF) working on natural resource governance, bioenergy and development of sustainable agroforestry value chains. She has over 25 years' work experience, most of which has been in action research and development projects on natural resource management, commercialization of forest and agroforestry products, agro-market linkages and value chain development. Her current work focuses on governance of woodfuel and aims to contribute to the development of sustainable charcoal value chains in Africa's drylands. She obtained her PhD from the University of Wales, Bangor. Her studies focused on the impacts of commercialization of non-timber forest products. Email: p.sola@cgiar.org

Miyuki liyama holds a PhD in Economics from the University of Tokyo. She has extensive experience in quantitative and qualitative analysis of integrated farming system evolutions, technological adoption and sustainable livelihoods in rural Africa. She has spent almost 20 years in East and Southern Africa conducting research on the evaluation of socio-economic and environmental viability of sustainable agricultural intensification within smallholder systems. She is currently the Research Strategy Director at the Japan International Research Centre for Agricultural Sciences (JIRCAS).

Irene Okeyo is a second year PhD student at the University of Queensland, Australia. She is involved in investigating water quality and phytoplankton dynamics in a subtropical marine bay along the Australian coast. She holds a Bachelor's and Master's degree in Environmental Studies and Climate Change from Kenyatta University, Kenya. Irene previously worked with ICRAF as a junior scientist. Her past research areas include environmental impact assessments; soil and water conservation technologies; and integration of legumes in smallholder farming systems. Email: rnokeyo@gmail.com

Mary Njenga is a bioenergy research scientist at ICRAF and a visiting lecturer at the Wangari Maathai Institute for Peace and Environmental Studies, University of Nairobi. Her research focuses on sustainable and efficient biomass energy production and use systems, and their link to the environment including climate change, livelihoods and rural-urban linkages. She holds a PhD

\footnotetext{
${ }^{*}$ Corresponding author
} 
from the University of Nairobi. Her area of speciality includes recovering bioenergy from organic residues and its implications on the environment. She has over 20 years of experience in research and development on dryland natural resource management, sustainable biomass for energy and biochar, circular bioeconomy for bioenergy and climate impact assessments. She has produced over 100 publications including journal papers, books and book chapters, policy and technical briefs. Email: m.njenga@cgiar.org

Ignatius Siko is a research fellow at ICRAF, currently working on supporting woodfuel research focusing on governance of woodfuel value chains in Kenya. He holds an MA in Environmental Policy from the University of Nairobi. His areas of interest range from environmental planning, policy formulation and analysis, renewable energy access and sustainability, natural resource use/management and sustainable development.Email: ignatius9439@gmail.com

Jonathan Muriuki is the Kenya country representative and an associate scientist at ICRAF, specializing in agroforestry systems and enhancing tree establishment practices on farms. His current activities involve support to development partners in land restoration projects focusing on natural regeneration of trees and associated practices. He has over 15 years' experience in research and development projects that span several countries in the East and Southern Africa region. He obtained his PhD from the University of Natural Resources and Applied Life Sciences (BoKU), in Vienna, Austria. Email: j.muriuki@cgiar.org 


\begin{abstract}
Biomass fuels remain a very important energy source for millions of Kenyans, consistently meeting close to $70 \%$ of domestic energy requirements over the decades. The charcoal sub-sector is one of the most important sources of employment and is reported to be a major source of livelihood for about 0.64 million people, with a market value worth billion. Woodfuel, especially in the form of charcoal, is produced in rural areas and consumed in peri-urban and urban areas, moving through connections between numerous actors, thus forming value chains and networks. The aim of this study was to conduct a literature review to investigate, document and map these value chains from production to consumption in order to assess overall economic significance of charcoal and identify opportunities and priority interventions for developing sustainable charcoal value chains. The value chain analysis approach was used to determine the flow of woodfuel and ascertain distribution of income and profit within and among groups of actors along the value chain.
\end{abstract}

The literature review established that the main value chain actors in Kenya comprise wood producers, charcoal producers, transporters, wholesalers, retailers and consumers. In some cases, the actors are supported by agents and brokers who facilitate linkages and transactions along various stages of the value chain. For many of the charcoal-producing households, income from sale of charcoal accounted for over $50 \%$ of the total household income. Monthly income of transporters was estimated to have increased more than 1,100 times between 2000 and 2013, with bribes paid at checkpoints accounting for $20-30 \%$ of the final retail price. Net profits of retailers were estimated to be $14 \%$. The charcoal value chain is dominated by men, except in retailing where women accounted for $57 \%$ of the actors. In addition, charcoal value chains do have negative environmental and health impacts which can be mitigated by adoption of appropriate production and consumption technologies.

The review shows that, charcoal value chains remain an important energy, livelihood and income source for many in Kenya but is increasingly associated with negative environment and health outcomes. However, in the short- to medium-term there is need to increase investments in the sub-sector and develop sustainable and competitive woodfuel value chains.

\title{
Keywords
}

Woodfuel, value chain, charcoal, biomass energy, gender, Kenya, greenhouse gases 


\section{Table of Contents}

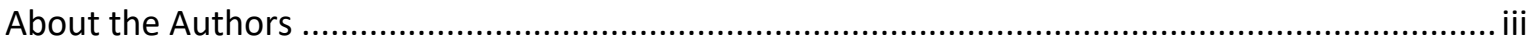

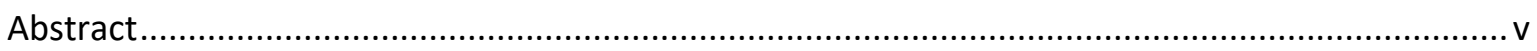

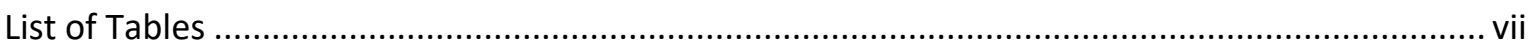

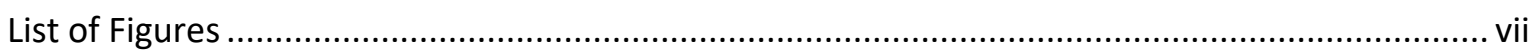

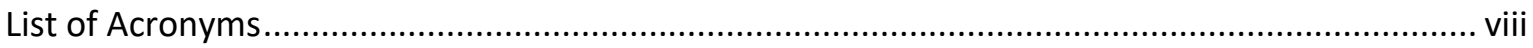

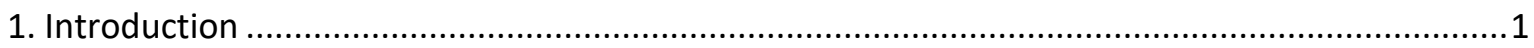

1.1 Woodfuel supply and demand dynamic ...................................................................

1.2 Woodfuel consumption in Kenya ............................................................................ 2

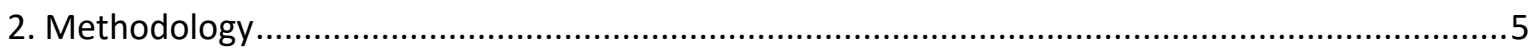

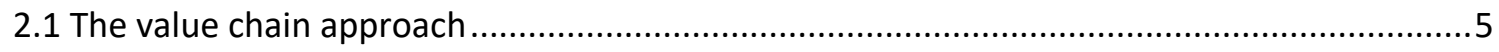

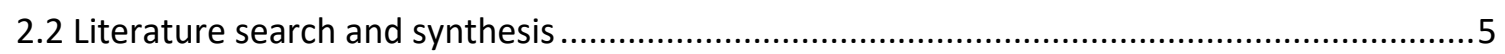

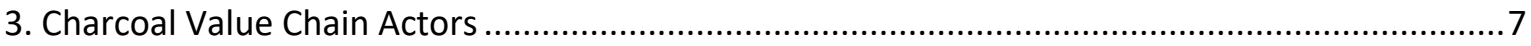

3.1 Overview of the charcoal sub-sector .................................................................... 7

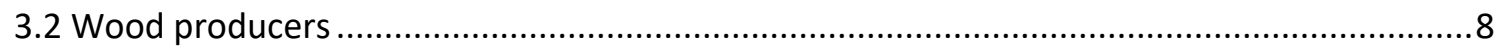

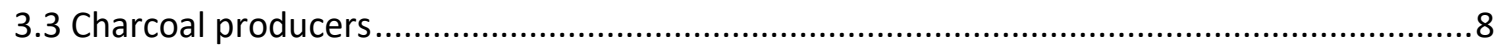

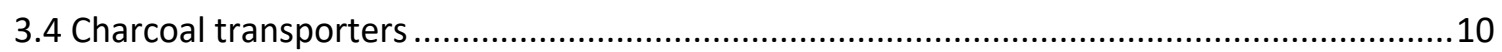

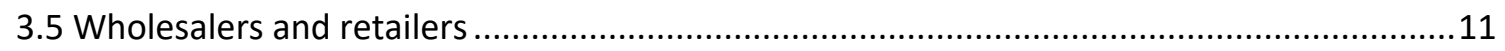

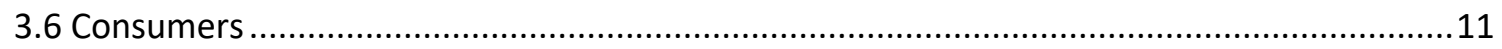

4. Elements and Economics of the Charcoal Value Chain in Kenya ...........................................12

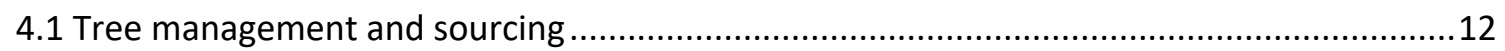

4.2 Charcoal production, technology and associated costs........................................... 14

4.2.1 Charcoal production hotspots ..................................................................... 14

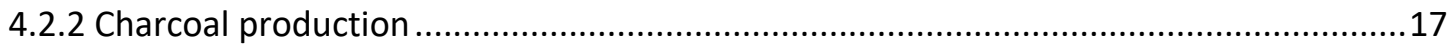

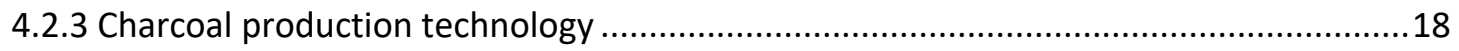

4.2.4 Charcoal producers' income........................................................................... 18

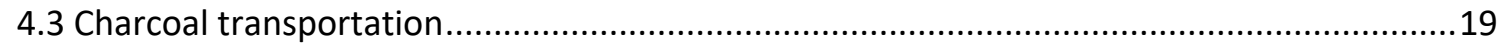

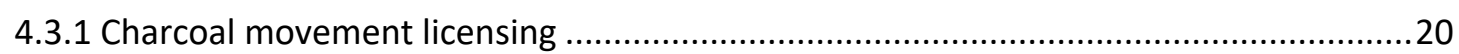

4.3.2 Income from charcoal transportation ..............................................................21

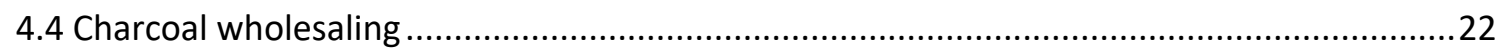

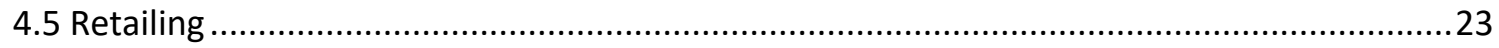

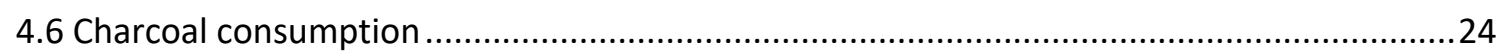

4.6.1 Household charcoal consumption and budget................................................25

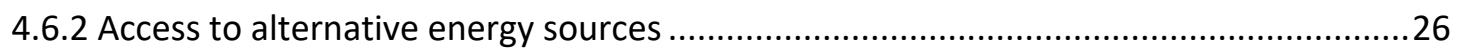

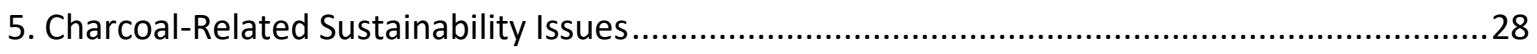

5.1 Deforestation and forest degradation...................................................................28

5.2 Climate change, GHG emissions and health outcomes ..................................................30

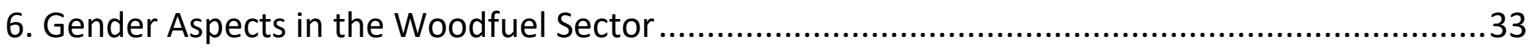

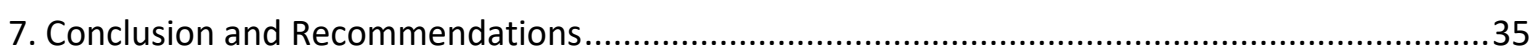

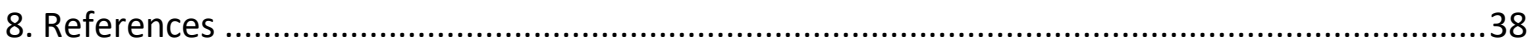

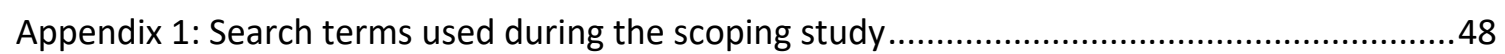




\section{List of tables}

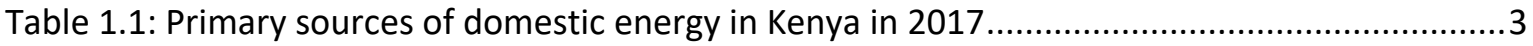

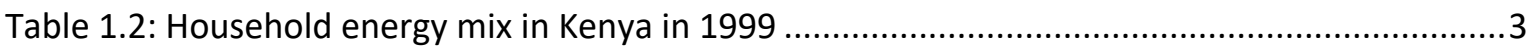

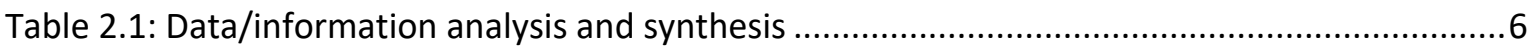

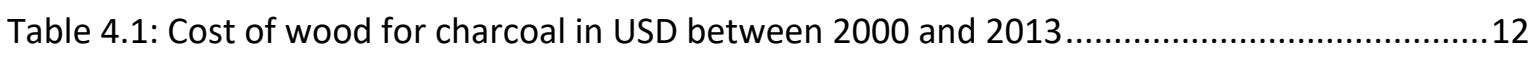

Table 4.2: Cost of fuelwood in USD from different counties in Kenya...........................................13

Table 4.3: Main charcoal-producing zones in Kenya covered in literature .....................................16

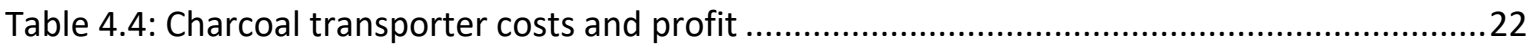

Table 4.5: Charcoal vendors expenses and profit share in a charcoal bag .....................................23

Table 4.6: Households energy expenditure based on income quartiles ..........................................26

\section{List of figures}

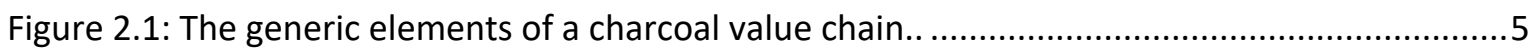

Figure 4.1: Different stages in preparation of the earth mound kiln: .........................................18

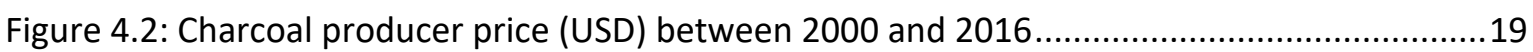




\section{List of Acronyms}

\begin{tabular}{|c|c|}
\hline AFF & African Forest Forum \\
\hline ALRI & Acute Lower Respiratory Infection \\
\hline ASAL & Arid and Semi-Arid Land \\
\hline CIFOR & Centre for International Forestry Research \\
\hline CPA & Charcoal Producer Association \\
\hline DFID & Department for International Development \\
\hline FAO & Food and Agriculture Organization of the United Nations \\
\hline FTA & Forests, Trees and Agroforestry \\
\hline GHG & Greenhouse Gases \\
\hline GLPGP & The Global LPG Partnership \\
\hline GoK & Government of Kenya \\
\hline GVEP & Global Village Energy Partnership \\
\hline GWP & Global Warming Potential \\
\hline $\mathrm{HH}$ & Household \\
\hline ICRAF & World Agroforestry \\
\hline ICS & Improved Cook Stove \\
\hline IEA & International Energy Agency \\
\hline KARI & Kenya Agricultural Research Institute \\
\hline КССТА & Kitui County Charcoal Transporters Association \\
\hline $\mathrm{KCJ}$ & Kenya Ceramic Jiko \\
\hline KES & Kenya Shilling \\
\hline KFS & Kenya Forest Service \\
\hline KIPPRA & Kenya Institute for Public Policy Research \& Analysis \\
\hline KNBS & Kenya National Bureau of Statistics \\
\hline LPG & Liquefied Petroleum Gas \\
\hline MENR & Ministry of Environment and Natural Resources \\
\hline MJ & Megajoule \\
\hline MoE & Ministry of Energy \\
\hline MT & Metric Tonnes \\
\hline NDU & National Defense University \\
\hline $\mathrm{NMHC}$ & Nonmethane hydrocarbons \\
\hline PLC & Private limited Company \\
\hline PM & Particulate Matter \\
\hline
\end{tabular}




$\begin{array}{ll}\text { ppm } & \text { parts per million } \\ \text { SEI } & \text { Stockholm Environment Institute } \\ \text { UN } & \text { United Nations } \\ \text { UN-DESA } & \text { United Nations Department of Economic and Social Affairs } \\ \text { UNDP } & \text { United Nations Development Program } \\ \text { UNEP } & \text { United Nations Environment Program } \\ \text { USA } & \text { United Sates of America } \\ \text { USD } & \text { United States Dollar } \\ \text { WHO } & \text { World Health Organization }\end{array}$




\section{Introduction}

Biomass fuels are very important for millions in Kenya, meeting over $70 \%$ of domestic energy requirements over the decades (Kendagor and Prevost 2013). With increased urbanization coupled with rapid population growth, of the middle to lower income groups, the demand is projected to grow in the coming decades. Charcoal is the most preferred form of energy in urban areas. It is used by more than $82 \%$ of urban households compared to $34 \%$ in rural areas (MoE, 2002). In addition, the charcoal sub-sector is one of the most important sources of employment, reported to be a major source of livelihood for as many as $66 \%$ of rural households in some areas (Angelsen et al., 2014). For many of the charcoal-producing households, income from the trade comprises over $50 \%$ of the total household income. In 2013, it was estimated that about 0.64 million people were formally or informally employed in the sub-sector and its market value was estimated at USD 1.6 billion, having registered a growth of $25 \%$ and $150-321 \%$ growth in jobs and market value respectively within a period of 13 years of (KFS, 2013).

\subsection{Woodfuel supply and demand dynamic}

In 2000, the total biomass fuel demand in Kenya was estimated at 34.3 million tonnes, of which 15.1 million was for firewood and 16.5 million for charcoal (IEA, 2015; Mugo and Gathui, 2010). Recent findings indicate that Kenya had a potential wood supply of 31.4 million $\mathrm{m}^{3}$ compared to a demand of 41.7 million $\mathrm{m}^{3}$, hence a deficit of 10.3 million $\mathrm{m}^{3}$ (MENR, 2013b). While firewood is mostly collected freely within a radius of less than $5 \mathrm{~km}$, most of the wood for charcoal (75-90\%) is harvested in woodlands and rangelands in the arid and semi-arid lands, that have low productivity of between 2-4\% per annum and poor regeneration of harvested trees (liyama et al., 2014a). Past studies reported a looming wood fuel crisis in the country based on the three physical indicators of diminishing supply (Nyang, 1999; GoK, 1997). These indicators were; i) a switch by households to poorer quality substitutes, especially agricultural residues; ii) increase in distances and consequently travel time to the source and iii) increase in amount of gathering time and effort per unit amount of woodfuel.

The three indicators have been observed in high agricultural potential areas like Nyeri (Boulkaid, 2015; Mwangi, 2013), Meru and Embu (Mugo and Gathui, 2010), and Kakamega (Wambua, 2011) as well as in marginal areas like Turkana, Mandera, (wa Gathui and Ngugi, 2010), Taita Taveta (Zschauer, 2012) and Garissa counties (Bizarri, 2010). During times of physical scarcity, well-off households substitute woodfuel with other modern fuels like LPG, while the poor are forced to 
switch to low quality fuels like crop residues and plastics, or change cooking and dietary habits to those that consume less fuel (wa Gathui and Ngugi, 2010; Wambua, 2011; GoK, 1997).

\subsection{Woodfuel consumption in Kenya}

Biomass energy accounts for $68 \%$ of the country's energy needs followed by petroleum products at $22 \%$, electricity at $9 \%$ and other forms of energy like solar and LPG at $1 \%$ (IEA, 2015). Rural households mainly use firewood while urban households prefer charcoal. By 2000 , about $89 \%$ of rural households were reported to use firewood for cooking compared to only $7 \%$ in urban areas (MoE, 2002). In comparison, it was reported that $82 \%$ of the population in urban areas compared to $34 \%$ in rural areas relied on charcoal for cooking (MoE, 2002). The per capita consumption of firewood was estimated at $741 \mathrm{~kg}$ and $691 \mathrm{~kg}$ in rural and urban areas respectively, while that of charcoal was estimated at $152 \mathrm{~kg}$ and $156 \mathrm{~kg}$, respectively (Mutimba and Barasa, 2005).

In a study based on the 2009 Kenya Housing and Population Census, 92.9\%, 4.8\%, 1.4\% and 0.9\% of rural households used firewood, charcoal, kerosene and LPG and other fuels respectively, as either their primary or secondary source of cooking fuel (KNBS, 2010). In comparison, $71.3 \%$ of peri-urban households used firewood, while $25.5 \%$ used charcoal. Moreover, $68.8 \%, 14.0 \%, 7.9 \%$ and $5.0 \%$ of the urban population use charcoal, paraffin, firewood and LPG respectively, as either a primary or secondary fuel. More recent statistics (Dalberg, 2018) based on the Kenya Integrated Household Budget Survey (KNBS, 2018) indicate that by 2017, the proportion of the urban population using firewood as their primary cooking fuel stood at $16.1 \%$, and those using charcoal and LPG was $21.9 \%$ and $27.6 \%$, respectively (Table 1.1 ). In rural areas, the population using firewood as the primary fuel stood at $84.3 \%$, while those using charcoal and LPG stood at $8.9 \%$ and $2.5 \%$, respectively.

While $82 \%$ of the urban population relied on charcoal for cooking compared to $34 \%$ in the rural areas (MoE, 2002). Studies by Kenya National Bureau of Statistics (KNBS) and Dalberg based on the 2009 Kenya Housing and Population Census showed the same trends of energy type consumption in 2005, 2009 and 2015 (Table 1.1; KNBS, 2007; KNBS 2009; KNBS, 2018; Dalberg, 2018). In 2004, Mutimba and Barasa (2005), estimated the per capita consumption of firewood to be at $741 \mathrm{~kg}$ and $691 \mathrm{~kg}$ respectively in the rural and urban areas and that of charcoal at $152 \mathrm{Kg}$ and $156 \mathrm{~kg}$ respectively.

These statistics indicate that there is a huge disparity in the fuel-use data in the country which Dalberg (2018) associates with use of multiple fuels at household level making it impossible to 
place a household into one category. A clear indication though is the rapid growth of LPG and declining use of firewood in provision of energy in the urban areas over the last decade.

Table 1.1: Primary sources of domestic energy in Kenya in 2005 and 2015

\begin{tabular}{|l|l|l|l|l|l|l|l|l|l|}
\hline Fuel type & \multicolumn{3}{|c|}{2005 (\% population) } & \multicolumn{3}{c|}{ 2009 (\% population) } & \multicolumn{3}{c|}{ 2015 (\% population) } \\
\hline & Overall & Urban & Rural & Urban & P-urban & Rural & Overall & Urban & Rural \\
\hline Firewood & 68.3 & 10.0 & 87.7 & 7.9 & 71.3 & 92.9 & 54.6 & 16.1 & 84.3 \\
\hline Charcoal & 13.3 & 30.2 & 7.7 & 68.8 & 25.5 & 4.8 & 14.6 & 21.9 & 8.9 \\
\hline Kerosene & 13.2 & 44.6 & 2.7 & 14.0 & & 1.4 & 14.0 & 29.0 & 2.3 \\
\hline LPG & 3.5 & 11.9 & 0.7 & - & & - & 13.4 & 27.6 & 2.5 \\
\hline Electricity & 0.6 & 1.8 & 0.2 & - & & - & 1.0 & 2.0 & 0.3 \\
\hline Other fuels & 1.1 & 1.5 & 1.0 & 5.0 & & 0.9 & 2.4 & 3.4 & 1.7 \\
\hline
\end{tabular}

Source: KNBS, 2007, 2010 and 2018

* (The 2010 study included LPG and electricity among other fuels while the two other studies had disaggregated the two; it also included the peri-urban area consumption of charcoal and firewood)

Energy use in Kenya defies the Energy Ladder Theory where a household is expected to transition from low quality energy sources like crop residues and firewood to higher quality sources like LPG and electricity, with increase in disposable income (KIPPRA, 2010; UNEP, 2006). Instead, over half of households in Kenya concurrently utilize several energy sources at a time (Table 1.1), a theory referred to as energy stacking (Nyang, 1999; GLPGP, 2013; Dalberg, 2018). Households however designate one source for majority of their cooking, which is referred to as the primary cooking energy source while the other less used types are either secondary or tertiary (Wambua, 2011; KIPPRA, 2010). Charcoal and LPG are used as secondary and tertiary fuels in many households nationally, a situation that might distort the overall consumption statistics if they are only based on primary fuels (Dalberg, 2018; Table 1.2).

Table 1.2: Household energy mix in Kenya in 1999

\begin{tabular}{|l|c|l|l|l|l|l|}
\hline & $\begin{array}{l}\text { Stacking } \\
\text { groups }\end{array}$ & Firewood & Kerosene & Charcoal & Electricity & $\begin{array}{l}\% \\
\text { population }\end{array}$ \\
\hline \multirow{2}{*}{ Rural areas } & 1. & \multicolumn{2}{|l|}{ Firewood + kerosene } & & 50.8 \\
\cline { 2 - 6 } & 2. & \multicolumn{2}{|l|}{ Firewood + kerosene + charcoal } & & 38.8 \\
\hline \multirow{2}{*}{ Urban areas } & 3. & & \multicolumn{2}{|l|}{ Kerosene + charcoal } & 29.6 \\
\cline { 2 - 6 } & 4. & & \multicolumn{2}{|l|}{ Kerosene + charcoal + electricity } & 24.4 \\
\hline
\end{tabular}

Source: Nyang, 1999

Woodfuel, especially in the form of charcoal is produced in rural areas and consumed in periurban and urban areas through connections between numerous actors forming the woodfuel value chains and networks. Two decades ago, $17 \%$ of the urban population that used firewood relied on purchased from the market while the rest collected it themselves from their own farms 
or other public and private lands (GoK, 2004). A decade later, statistics indicate that the situation had reversed with urban households relying mainly on market supply (GLPGP, 2013; Dalberg, 2018) except for $20 \%$ of firewood users who collect for themselves from open spaces (UN-DESA, 2004). In the rural areas, $67 \%$ of the households who use charcoal and $24 \%$ of those that use firewood rely on the market while the rest collect for themselves. The households that collect wood for free were predominantly poor households located in rural areas while the mid-highincome households in both the high agricultural potential rural and urban areas mostly either purchase woodfuel or rely on other cleaner fuels like LPG (GLPGP, 2013; Mwangi, 2013; Hosier, 1985).

Other major consumers of woodfuel in the country are the cottage industry and institutions estimated to consume about 1.8 million tonnes of firewood and 0.43 tonnes of charcoal (converted from 4.3 million tonnes of wood using earth mound kilns with 10\% efficiency (Mugo and Gathui, 2010)). This comprised about $12 \%$ of the firewood and $27 \%$ of the charcoal consumed in the country that year (Mugo and Gathui, 2010; IEA, 2015). Within the cottage industry sector, restaurants and food kiosks (especially eateries that serve roast meat) are the largest consumers, accounting for over $91 \%$ of the demand -1.28 tonnes comprised firewood, while 4.28 tonnes comprised wood for charcoal. Thus, the woodfuel, especially in the form of charcoal, is produced in rural areas and consumed in peri-urban and urban areas through connections between numerous actors, forming the woodfuel value chains and networks.

In the last decade the government enacted forestry legislations and charcoal rules to support, guide and control woodfuel value chains. The sub-sector provides livelihoods, affordable energy, income and employment for many. However, this has ensured the viability of this energy subsector and in early 2018, production and trade of charcoal was banned, under the logging Moratorium and Charcoal Ban Gazette Notice of $2018^{1}$.

The aim of this study was to conduct a literature review to investigate, map and document these value chains from production to consumption in order to, i) assess overall economic significance of charcoal, ii) identify and gauge trends of development and, iii) identify priority interventions for developing sustainable charcoal value chains.

\footnotetext{
${ }^{1}$ http://www.environment.go.ke/wp-content/uploads/2018/11/4048264.pdf; https://www.nation.co.ke/news/Tobiko-extendslogging-ban/1056-5357104-x76lbcz/index.html
} 
This study will inform development and engagement interventions within the CIFOR-led four-year program on sustainable woodfuel value chains, a component of the EU-funded program 'Governing Multifunctional Landscapes in Sub-Saharan Africa'

\section{Methodology}

\subsection{The value chain approach}

The value chain approach seeks to investigate activities implemented by all actors from production to consumption, including linkage service providers (van den Berg et al., 2009). The approach aims to understand the direction of the flow of economic goods and services among different actors at different stages of engagement in the production, distribution/transportation, trading and consumption (KFS, 2013; Ndegwa, 2010; Sepp, no date). According to Sepp (No date), the charcoal value chain has six generic stages and categories of actors as shown in Figure 2.1.

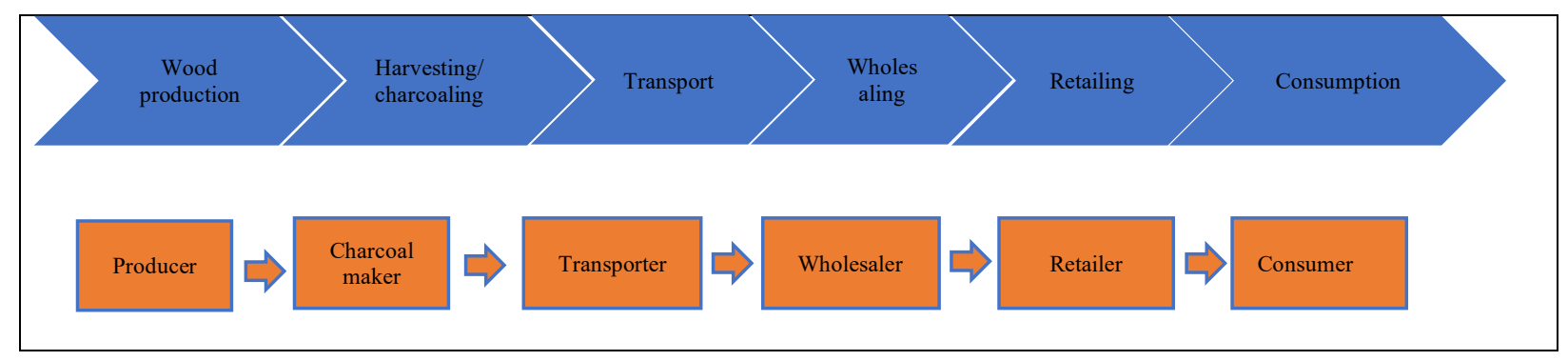

Figure 2.1: The generic elements of a charcoal value chain. Source: Sepp, no date

Not every value chain features all these generic elements and the shorter the value chain, the higher the likelihood of the key actors getting more benefits. Introduction of other agents into the value chain leads to sharing of benefits among the actors, thus making the products more expensive for the final consumer (Ndegwa 2010; Ndegwa et al., 2011). Once the key elements and categories of actors are mapped out in the value chain framework, quantifiable data on income and profit, prices and quantities of goods handled by the different actors, will be added as documented in literature. Using this information, an economic analysis will be conducted to ascertain distribution of income and profit within and among various groups along the value chain.

\subsection{Literature search and synthesis}

The study is based on a literature review that was guided by five components i) study characteristics which were used to screen for inclusion, ii) trade flows detailing trade routes, 
governance systems, actors, etc. iii) levels of demand and markets describing volume of trade, prices, characteristics of consumers, iv) supply/supply zones covering hotspots, tree species used, sources of trees, levels of production, etc. v) key sustainability issues like production systems and technologies, environmental and health outcomes, and gender issues regarding tree ownership and access, roles of men and women in the value chain.

The systematic search was conducted using Boolean search logic where keywords are combined with operators such as AND, NOT and OR. Online searches were conducted from various bibliographic databases (Scopus, Google Scholar, Taylor and Francis, and Web of Science) as well as websites of key woodfuel support organizations. Both original research articles and review articles were included in this study. Table 2.1 presents a summary of the focus of the search. The study was undertaken from April to June 2018 with 961 articles retrieved and 103 used in data/information extraction after screening for relevance. The data/information extracted was logged into an Excel spreadsheet and synthesized into the report.

Table 2.1: Data/information analysis and synthesis

\begin{tabular}{|c|c|c|}
\hline & Study focus & Data/information needs \\
\hline $\begin{array}{l}\text { Study } \\
\text { characteristics }\end{array}$ & $\begin{array}{l}\text { - } \text { Reference author } \\
\text { - } \text { Publication year } \\
\text { - Reference type (ex. journal; gov report; } \\
\text { report; media consultancy) Reference } \\
\text { quality (ex. scientific/data) }\end{array}$ & $\begin{array}{l}\text { - Focus wood fuel (charcoal, firewood, both) } \\
\text { - Relevance for VC }\end{array}$ \\
\hline $\begin{array}{l}\text { Summary } \\
\text { trade flows }\end{array}$ & $\begin{array}{l}\text { - } \text { Description of the route } \\
\text { - } \text { Mode of transport } \\
\text { - } \text { Countries/regions covered by trade } \\
\text { - } \text { Major markets } \\
\text { - } \text { Major production hot spots }\end{array}$ & $\begin{array}{l}\text { - } \text { Key cross-border areas } \\
\text { - Description of major players } \\
\text { - Description of governance systems } \\
\text { - Description of significant sustainability } \\
\text { issues } \\
\text { - Value chain margins }\end{array}$ \\
\hline $\begin{array}{l}\text { Demand/ } \\
\text { markets }\end{array}$ & $\begin{array}{l}\text { - } \text { County } \\
\text { - } \text { Major market } \\
\text { - } \text { Population size of the major market } \\
\text { - } \text { major consumers } \\
\text { - } \text { the majimated \% or number of consumers in } \\
\text { - Estimated annual demand of charcoal/ } \\
\text { firewood in the city }\end{array}$ & $\begin{array}{l}\text { - } \text { Where woodfuel is sourced } \\
\text { - } \text { Main species used } \\
\text { - } \text { Unit of sales (ex. Bag, tins) } \\
\text { - High-season (months) } \\
\text { - } \text { High-season unit price } \\
\text { - } \quad \text { Low-season (months) } \\
\text { - } \quad \text { Key governance regarding trade } \\
\text { - } \quad \text { Key players in the sector }\end{array}$ \\
\hline $\begin{array}{l}\text { Supply/supply } \\
\text { zones }\end{array}$ & $\begin{array}{l}\text { - Major hotspots } \\
\text { - Population of the area } \\
\text { - Socio-economic characteristics of the } \\
\text { major producers } \\
\text { - Estimated \% or number of producers in the } \\
\text { - Mrea }\end{array}$ & $\begin{array}{l}\text { - Tree sources } \\
\text { - Tree species } \\
\text { - Type of harvesting } \\
\text { - Type of processing }\end{array}$ \\
\hline
\end{tabular}




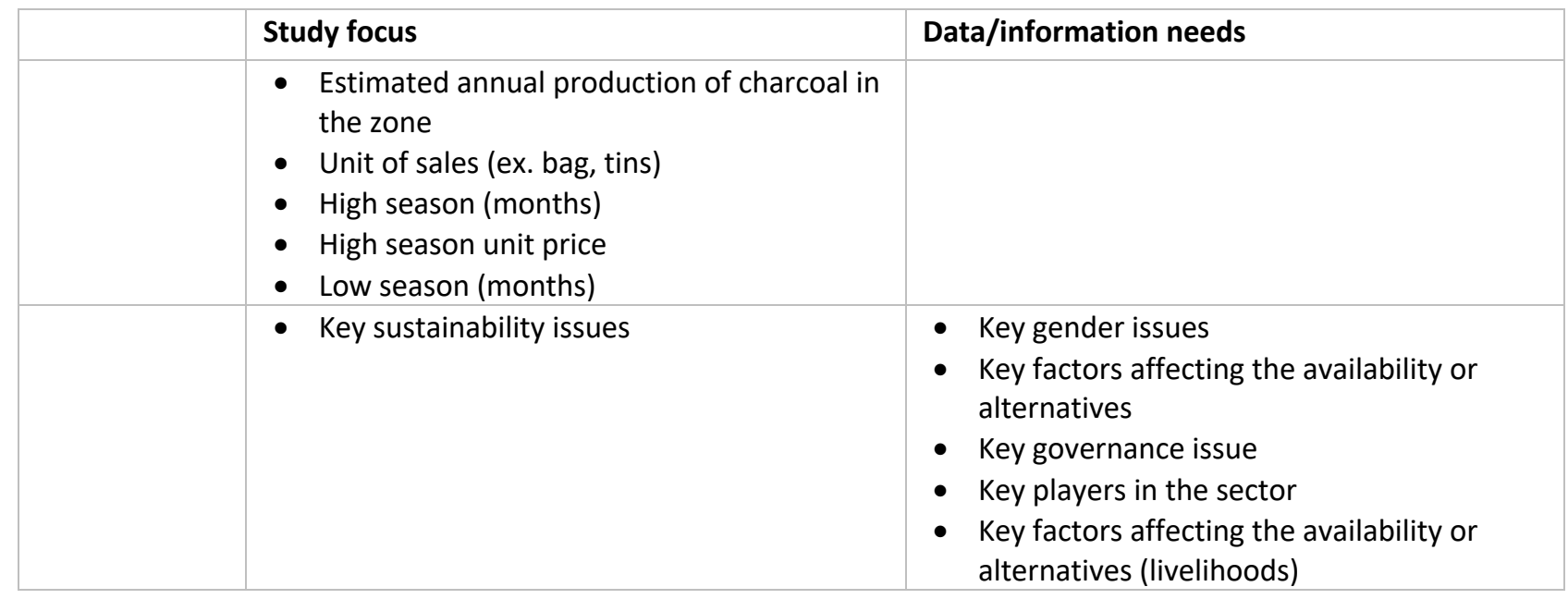

\section{Charcoal Value Chain Actors}

\subsection{Overview of the charcoal sub-sector}

The charcoal sub-sector is one of the most important sources of employment in the country with reports indicating that it had employed about 0.5 million people as producers, traders and transporters by the year 2000. These beneficiaries further supported over 2 million people as dependants (Mutimba and Barasa, 2005). In the same year, the sub-sector was reported to have a market value of KES 32 billion (USD 427 million at the prevailing exchange rate), highlighting the important role it plays in the Kenyan economy (Mutimba and Barasa, 2005).

By 2013 , the subsector had grown by $25 \%$ in jobs to employ an estimated 0.64 million people and $150-321 \%$ in market value to about KES135 billion (USD 1.6 billion) within the intervening period of 13 years (KFS, 2013). Within the same period, charcoal consumption countrywide had grown from an annual rate of 1.6 million tonnes (Mutimba and Barasa, 2005), to 2.5 million tonnes by 2009 (KFS 2013).

The charcoal value chain starts from tree production followed by harvesting, charcoal making (carbonization), transportation and trade at various levels (KFS, 2013; Ndegwa, 2010; Sepp, no date). The main value chain actors are wood producers, charcoal producers, transporters, vendors (wholesalers and retailers), and consumers. In some cases, the actors are supported by the services of agents and brokers facilitating linkages and transactions between various stages of the value chain. Since most of the production is based on earth mound kilns that have about $10 \%$ efficiency, the current charcoal production level requires 10 tonnes of wood to produce one 
tonne of charcoal (Mugo and Gathui, 2010; IEA, 2015;). About 40-75\% of the charcoal is produced in arid and semi-arid lands (KFS, 2017; liyama et al, 2014; Burrow and Mogaka, 2007) and especially in the Eastern region (Tharaka Nithi, Kitui Makueni and Machakos counties), Rift Valley region (Narok, Kajiado, Baringo, Laikipia, Turkana counties), Coastal region (Kilifi, Kwale, Taita Taveta and Tana River counties ) and North Eastern region (Marsabit and Garissa counties) (GoK, 2018; MENR, 2015; Burrow and Mogaka, 2007; GoK, 1997).

Nairobi is the largest charcoal market in the country accounting for $10 \%$ of all the charcoal consumed (MENR, 2013). The Nairobi supply network spreads across the Rift Valley, Eastern and North Eastern (Garissa) regions (Onekon and Kipchirchir, 2016; MENR, 2015). According to Onekon and Kipchirchir (2016), 35\% of the charcoal sold in Nairobi comes from Narok, while 20\% each comes from Kajiado and Ukambani.

\subsection{Wood producers}

These are the tree growers or owners mostly residing in rural areas. They may either personally produce charcoal or sell/give the trees to producers (KFS, 2013; Bailis, 2005). According to Mutimba and Barasa (2005), in the year 2000, $44 \%$ of the charcoal consumed in the country was produced from trees in the producers; own land, 38\% from private land owned by other parties, $13 \%$ from land owned by the government and 5\% from communal lands. In 2013, majority of the trees were harvested in private lands but there was a substantial amount of charcoal coming in from neighbouring countries mainly - Tanzania, Uganda, Ethiopia and Somalia (KFS, 2013).

Women representation is limited at the wood production and carbonization stages of the charcoal value chain (Delahunty-Pike, 2012; Mutimba and Barasa, 2005), since traditions dictate that land and the resources thereof belong to men, including both planted and naturally growing trees (Zschauer, 2012; GoK, 2011; Muchiri, 2008). This means that wood production is dominated by men, except in women-headed households.

\subsection{Charcoal producers}

Charcoal producers harvest the wood and carbonize it into charcoal. Majority of them are based in rural areas where trees are in abundance. At the charcoal production stage, there is minimal representation of women because production activities like tree felling and kiln preparation are physically demanding and therefore regarded as more suited to men (Delahunty-Pike, 2012; Ndegwa, 2017). Indeed, statistics show that in 2000 , only $16 \%$ of charcoal producers in Kenya were women, while $84 \%$ were men (Mutimba and Barasa, 2005). However, the statistics need to 
be read with caution as charcoal production is mostly a family business as demonstrated by Ruuska (2012) in a study conducted in Kilifi County. According to the findings, $27.5 \%$ of all charcoal in the area was produced by women, while another $41.5 \%$ was produced with the input of women as part of the family. Furthermore, KFS (2013) reported that more women than men are registered as charcoal producers with CPAs in Kitui County. Having more women registered with CPAs as charcoal producers may also signify women's willingness to engage in legal production compared to men who had largely dominated production before the enactment of the Charcoal Rules (2009). According to Mutimba and Barasa (2005), there are four categories of producers:

i. Sow and reap producers: These producers are usually located in the high agricultural potential areas like Meru and Muranga counties and produce charcoal from planted trees sourced from their own farms.

ii. Salvage producers: Produce charcoal from land cleared for other activities like agricultural expansion (in Narok) or control of invasive species (in Baringo and Garissa).

iii. Sideline producers: They are wage labourers who are; either i) paid using wood to produce charcoal; or ii) given trees to produce charcoal yet expected to give a share of the charcoal to the tree owner. This is common in arid and semi-arid lands (ASALs) where there are group and private ranches.

iv. Sneak and snip producers: This category involves those who sneak into governmentprotected areas (forests) and illegally harvest trees to produce charcoal.

Nationally, charcoal is produced by $200,000-300,000$ producers spread across the major producing zones in Rift Valley, Eastern, Coast and North Eastern (Mutimba and Barasa, 2005; KFS, 2013). Even though this might seem like an insignificant figure considering the total population of about 48 million, localized studies indicate that charcoal production is a major livelihood resource for rural population in the arid lands. For instance, in Mutomo District, Kitui County, Ndegwa et al. (2016b) reported that $52 \%$ of the respondents engage in charcoal production, while Kiruki et al. (2016) reported $66 \%$ in the same area. Ruuska (2012) reported that $51 \%$ of households were involved in charcoal production in Dakacha, Kilifi County.

There are two main categories of charcoal producers: full-time producers who undertake it as a business, and; part-time or seasonal producers who only produce when they need money to meet a certain need or during drought (Kiruki et al, 2016; Ndegwa et al., 2016b; Ruuska, 2012; Mutimba and Barasa, 2005). At the national level, Mutimba and Barasa (2005) reported that $56 \%$ of the 
producers are full-time, while $44 \%$ are part-time. In his findings from a study conducted in Kitui County, Njoroge (2013) reported that $76 \%$ of the respondents were part-time producers while $24 \%$ engaged in production on a full-time basis.

In addition, charcoal producers can also be divided into three major groups based on the level of production. The three groups are: small-scale producers who produce less than 10 bags per month; medium-scale producers who produce up to 100 bags per month, and; large-scale producers who produce over 100 bags per month (Ruuska, 2012). Small-scale producers are mostly poor people with less diversified sources of income and, in many cases, engage in production for subsistence purposes (Ndegwa et al., 2016b). Full-time producers who happen to be either medium- or large-scale are the wealthy people able to finance large-scale charcoal production operations (Ndegwa et al., 2016b; KFS, 2013). It is the latter category that poses the greatest risk to forest and land degradation due to their high and unsustainable demand for biomass.

\subsection{Charcoal transporters}

Transporters usually buy and transfer charcoal from producers in rural areas and sell it to either wholesalers and/or retailers (KFS, 2013; Ndegwa, 2010). In some instances, they also sell directly to consumers, especially in urban areas. Charcoal transportation is mainly dominated by men who accounted for $86 \%$ of the transporters in 2000 , compared to women who accounted for only $14 \%$ as reported by Mutimba and Barasa (2005). Women are reported to play a significant role in small-scale transportation especially where human labour, bicycles or donkey carts are used (Delahunty-Pike, 2012). The large-scale and long-distance transportation is dominated by men who have the required capital to invest in motorized means of transport. Involvement of women in transportation is also curtailed by other factors such as unfamiliarity with the complicated and sometimes long legal procedures to get permits, as well as rampant corruption (Ndegwa, 2017; Delahunty-Pike, 2012). Further, women might be reluctant to undertake travel that requires them to spend nights away from home for domestic and/or security reasons. Enactment of the Charcoal Rules (2009) has however, seen an increased interest by women as charcoal transporters with $30 \%$ of transporters registered with the Kitui County Charcoal Transporters Association (KCCTA) being women (KFS, 2013). 


\subsection{Wholesalers and retailers}

Wholesalers purchase charcoal in bulk from either producers, transporters or brokers and sell to retailers, and in some cases to consumers in bags (KFS, 2013; Ndegwa, 2010; Mutimba and Barasa, 2005). On the other hand, retailers buy charcoal from either producers, transporters or wholesalers and sell to consumers either in bags or smaller units like buckets and recycled tins. The wholesale industry is dominated by men who can afford the required huge capital outlay to buy a large consignment for resale (Delahunty-Pike, 2012). However, charcoal retail is dominated by women who account for $57 \%$ of all retailers (Mutimba and Barasa, 2005). Delahunty-Pike (2012) attributes this to the minimal capital outlay required to buy a few sacks of charcoal and sell them in small units like tins and buckets.

\subsection{Consumers}

Consumers are at the end of the value chain. A majority are households, but commercial businesses (such as hotel, restaurants, roast meat eateries) and institutions (such as schools, hospitals, prisons) also form a significant portion of the final consumers. Charcoal is sold to commercial businesses in 35-kg bags, while majority of households purchase in either 35-kg bags or 2-kg recycled tins (KFS, 2013, Mutimba and Barasa, 2005). At the consumption stage, household cooking is almost entirely the responsibility of women, so they are the main charcoal consumers (GoK, 2011; Muchiri, 2008). In urban areas, majority of the non-household charcoal consumers are small to medium sized enterprises. According to Karekezi et al. (2008) most of the charcoal-dependent enterprises are owned by women (70\%). This means that the majority of charcoal consumers within cottage industries are also women. 


\section{Elements and Economics of the Charcoal Value Chain in Kenya}

\subsection{Tree management and sourcing}

Most of the charcoal in Kenya is produced from trees that are obtained at no cost either from private or government land (UNEP, 2017; IEA, 2015; Tesot, 2012; Mutimba and Barasa 2005; DFID, 2002), which makes the price of charcoal "artificially" low compared to when producers purchase or grow wood for charcoal (KFS, 2013; Nyang, 1999). Even though the charcoal production largely relies on trees from private lands, few producers are said to be involved in tree planting for charcoal as most of them rely on naturally regenerating trees (Mutimba and Barasa, 2005; Ndegwa, 2010). Furthermore, between $90-99 \%$ of this charcoal is produced in rudimentary earth mound kilns (KFS, 2013; Mutimba and Barasa, 2005) with efficiencies ranging from $8 \%$ to $20 \%$, depending on the moisture content of the wood and operator experience (Ndegwa, 2016; liyama et al., 2014). About 8-10 tonnes of wood is required to produce a tonne of charcoal, signifying massive wastage of biomass resources; there are technologies with three- or four-times more efficiency such as, the improved earth kiln, the half-orange brick kiln (IEA, 2015; Mugo and Gathui, 2010; Bailis, 2005; Nyang, 1999).

Nevertheless, a few isolated cases have revealed that charcoal producers can produce charcoal from woody residues especially planted for charcoal and make profits at the prevailing market rate. One such example is Kakuzi PLC in Murang'a County which used to produce charcoal from residues of Eucalyptus that had been grown and cut for poles, using a half-orange brick kiln with an efficiency of about 30\% (Oduor, 2012; Mugo and Gathui, 2010). From their analyses, the cost of wood required to produce a bag of charcoal was KES 75 (about USD 0.93) ${ }^{2}$. Other studies in 2000 estimated the cost of wood required to produce a bag of charcoal to be between USD 0.29 and USD 0.59, and about USD 1.44 in 2013 as shown in Table 4.1.

Table 4.1: Cost of wood for charcoal in USD between 2000 and 2013

\begin{tabular}{|l|l|l|l|l|}
\hline $\begin{array}{l}\text { Year of } \\
\text { study }\end{array}$ & \multicolumn{2}{|l|}{ Cost of a bag of charcoal } & $\begin{array}{l}\text { Exchange rate } \\
\text { (1USD to KES) }\end{array}$ & Reference \\
\hline & (KES) & USD & & \\
\hline 2000 & $22-44$ & $0.29-0.59$ & 76 & Bailis, 2005 \\
\hline 2010 & 100 & 1.25 & 80 & Ndegwa, 2010 \\
\hline 2010 & 75 & 0.59 & 80 & $\begin{array}{l}\text { Mugo and } \\
\text { Gathui, } 2010\end{array}$ \\
\hline 2013 & 125 & 1.44 & 87 & KFS, 2013 \\
\hline
\end{tabular}

\footnotetext{
2 See prevailing exchange rate in Table 4.1
} 
Assuming a kiln efficiency of $10 \%$ and the weight of a bag of charcoal is $35 \mathrm{~kg}$ as stated by Mutimba and Barasa, (2005), it can be deduced that $350 \mathrm{~kg}$ of wood for charcoal was priced at USD 0.25-1.44. This low valuation of wood for charcoal is particularly one of the reasons the farmgate price of charcoal has remained low. In fact, Table 4.2 demonstrates that the farmgate price of $350 \mathrm{~kg}$ of firewood was about USD 9.4 in 2010 (Ndegwa, 2010) while retail price was about USD 22.4 in 2009 (Ngetich et al., 2015) and USD 27 in 2015 (Boulkaid, 2015).

Table 4.2: Cost of fuelwood in USD from different counties in Kenya

\begin{tabular}{|l|l|l|l|l|l|}
\hline $\begin{array}{l}\text { Year of } \\
\text { study }\end{array}$ & $\begin{array}{l}\text { Cost of wood in KES } \\
\text { (units in brackets) }\end{array}$ & $\begin{array}{l}\text { Cost of } \mathbf{3 5 0} \\
\text { kg of wood }\end{array}$ & $\begin{array}{l}\text { Exchange rate } \\
\text { (1USD KES to) }\end{array}$ & Location & Reference \\
\hline 2009 & $500\left(0.17 \mathrm{~m}^{3}\right)^{*}$ & $22.4^{* * *}$ & 80 & Nakuru & $\begin{array}{l}\text { Ngetich et al., } \\
2009\end{array}$ \\
\hline 2010 & $800(1$ stere*) & $9.4^{* *}$ & 80 & Murang'a & Ndegwa, 2010 \\
\hline 2011 & $76(25 \mathrm{~kg} \mathrm{headload)}$ & $12^{* *}$ & 89 & Kakamega & Wambua, 2011 \\
\hline 2015 & $200(25 \mathrm{~kg})$ & $27.0^{* * *}$ & 103 & Nyeri & Boulkaid, 2015 \\
\hline
\end{tabular}

${ }^{*} 1$ stere $=0.65 \mathrm{~m}^{3}=374 \mathrm{~kg} ; 1 \mathrm{~m}^{3}=575 \mathrm{~kg}$. (FAO, 2004); ${ }^{* *}$ Farm gate price; ${ }^{* * *}$ Retail price

Considering the farmgate price of firewood was USD 9-12 around the year 2010 (Table 4.2), and the cost paid for wood for charcoal (when it was paid) in the same period was USD 0.6-1.5 (Table 4.1), it can be concluded that wood for charcoal is undervalued 10 times compared to firewood. Due to this, studies report that the portion of the final retail price of charcoal retained by tree producers is 0-6\% (FAO, 2017; KFS, 2013; Bailis, 2005), thus making investment in tree farming for charcoal quite unattractive (MENR, 2013b; liyama et al., 2017).

According to Mutimba and Barasa (2005), the most preferred tree species for charcoal production nationally are Acacia spp, (45\%), Olea spp (9.5\%) and Croton megalocarpus (7\%) in that order. Acacias A. Senegal, A. seyal, A. tortilis, A. nilotica, A. mellifera, A. polyacantha and A. xhanthophloea are some of the most preferred (Ndegwa et al., 2016a; Onekon and Kipchirchir, 2016; KFS, 2013; GoK et al., 1997). Other trees are commonly used in localities where they are in abundance. These include Prosopsis juliflora in Baringo, Turkana, and Garissa counties (KFS, 2013), Terminalia brownie in Kwale county (Wanjala, 2016), Olea Africana and Warbugia ugandensis in Narok county (Tesot, 2012) and Terminalia prunoides, Terminalia brownii, Senna abbreviata and Balanites aegyptica in Kitui county (Luvanda et al., 2016; Ndegwa et al., 2016a).

The Acacia spp., among other hardwood trees, are preferred for charcoal production because they produce dense high-quality charcoal that lasts long in the cooking stove (Ndegwa et al., 2018; Onekon and Kipchirchir, 2016; Zschauer, 2012; Mutimba and Barasa, 2005). While 
harvesting in Narok and Kajiado counties is usually through clear-felling to open up land for agriculture (liyama et al., 2017; KFS, 2013; Tesot, 2012; Bailis, 2005; Mutimba and Barasa, 2005), harvesting in the eastern and coastal regions is usually selective where preferred hardwood trees like Acacia spp are harvested, leaving the less desirable softwood trees like Commiphora spp (Ndegwa et al., 2018; Kiruki et al., 2016; Burrow and Mogaka, 2007). The latter has led to depletion of targeted species, and consequently loss of biodiversity in the woodlands (liyama et al, 2017; Kiruki et al., 2016; Ndegwa et al., 2016a; Onekon and Kipchirchir, 2016).

\subsection{Charcoal production, technology and associated costs}

\subsubsection{Charcoal production hotspots}

Majority of the charcoal consumed in the country is produced in ASALs (GoK, 2018; liyama et al, 2014; Burrow and Mogaka, 2007). These cover over $70 \%$ of the country's land mass and can be found in almost all regions of the country. From the literature reviewed, several regions or charcoal-producing zones have been extensively studied due to their importance in supply and localized impact on the ecosystem (Table 4.3).

The Mau ecosystem, spanning Narok, Nakuru, Kakamega and Migori counties has been studied extensively and 17 of the reviewed studies focus on it. The forests of focus in the Mau ecosystem include: Nyakweli Forest, Kakamega Forest, West and East Mau Forest Reserve, Maasai Mau Forest and Burnt Forest. Literature indicates that excisions and conversion of excised forest land into agricultural land is the leading cause of deforestation in the area. Wood from forest clearance is also used for charcoal production (liyama et al., 2017; KFS, 2013; Tesot, 2012; Kipsisei, 2011; Bailis et al, 2005). In addition, some of the publications report of illegal charcoal production inside protected forests especially close to the excision frontier (liyama et al., 2017; Kipsisei, 2011). Some of the reported impacts of charcoal production in the area include degradation of catchment areas leading to reduction in water levels in rivers originating from the area. Loss of biodiversity, loss of ecosystem services, land degradation and extreme weather events are the other impacts reported by the studies as resulting from indiscriminate felling of trees for agriculture and charcoal production.

Kitui and Makueni counties in the Ukambani region are the next most studied charcoal production zones. Charcoal production in this region is mostly through selective logging. Many of the private farmlands and non-protected government and communal lands have been highly depleted of preferred charcoal production tree species (Ndegwa et al., 2018; liyama et al, 2017; Kiruki et al, 
2016; Ndegwa et al., 2016a; KFS, 2013; Ndegwa 2010). As a result, production has extended into protected forests and woodlands like the Kitui South National Reserve which is meant to be a wildlife conservancy and migration corridor (Ndegwa et al., 2018; KFS, 2013). In addition, charcoal producers are also reported to cut trees on hillsides that have in the past enjoyed community protection because of their critical role as water catchments and source of pasture during drought. Loss of ecosystem services and danger of desertification due to unsustainable charcoal production practices are some of the concerns raised in the publications (liyama et al, 2017; Kiruki et al, 2016; Ndegwa et al., 2016a).

The coastal region comprising Kilifi, Kwale and Taita Taveta counties is the third most studied charcoal production zone. Dakacha woodlands in Kilifi and Shimoni Forest in the South Coast are some of the forests covered in the literature (Boulkaid, 2015; Birdlife International, 2013; Ruuska, 2012; Zschauer, 2012). Main observation made in the literature is that charcoal production is rampant in protected forests leading to depletion of tree species preferred for charcoal. Kajiado and the central region are the other key charcoal production sites highlighted as charcoal production hotspots as shown in Table 4.3. 
Table 4.3: Main charcoal-producing zones in Kenya covered in literature

\begin{tabular}{|c|c|c|c|c|c|}
\hline Region/zone & County(s) & Example of forest & $\begin{array}{l}\text { No. of } \\
\text { studies }\end{array}$ & References & Main issues highlighted in literature \\
\hline $\begin{array}{l}\text { Mau } \\
\text { ecosystem }\end{array}$ & $\begin{array}{l}\text { Narok } \\
\text { Kakamega } \\
\text { Nakuru } \\
\text { Migori }\end{array}$ & $\begin{array}{l}\text { Nyakweli forest- } \\
\text { Narok } \\
\text { Kakamega Forest- } \\
\text { Kakamega } \\
\text { West Mau Forest } \\
\text { reserve } \\
\text { Maasai Mau } \\
\text { Forest } \\
\text { Eastern Mau } \\
\text { Forest Reserve } \\
\text { Burnt Forest }\end{array}$ & 17 & $\begin{array}{l}\text { GoK, 2018; liyama et al., 2017; } \\
\text { Bailis, 2009; Bailis et al, 2005; } \\
\text { KFS, 2013; Wambua 2011; Ngetich et al, } \\
\text { 2009; Onekon and Kipchirchir, 2016; } \\
\text { KFS, 2017; Chabeda-Barthe, 2013; } \\
\text { Tesot, 2012; Njenga et al, 2013; Wanjala } \\
\text { et al, 2015; Butynski and de Jong, 2016; } \\
\text { Kipsisei, 2011; Ngaira and Omwayi, } 2012\end{array}$ & $\begin{array}{l}\text { Land opened up for agriculture leading to deforestation is used for charcoal } \\
\text { Production from indigenous species within protected forests } \\
\text { Illegal settlements and charcoal production taking place in protected forest reserves. } \\
\text { Deforestation and degradation could lead to loss of pastures, loss of biodiversity, loss of } \\
\text { ecosystem services and extreme weather events like floods and drought. } \\
\text { Forest excision a major cause of deforestation and degradation } \\
\text { Most production activities in protected forests occurs close to the borders with the land } \\
\text { exercised from the protected forest } \\
\text { Heavy browsing in degraded forests affects natural regeneration } \\
\text { Indiscriminate felling of wood has reduced water levels in Mara and Migori Rivers } \\
\text { Destruction of water catchment led to reduction in water volumes in River Mau and Sondu } \\
\text { Miriu }\end{array}$ \\
\hline Ukambani & $\begin{array}{l}\text { Kitui } \\
\text { Makueni }\end{array}$ & $\begin{array}{l}\text { South Kitui } \\
\text { National Reserve }\end{array}$ & 16 & $\begin{array}{l}\text { GoK, 2018; Ndegwa et al., 2018; } \\
\text { Ndegwa et al., 2016a; KFS, 2013; } \\
\text { Ndegwa 2010; Bar and Ehrensperger, } \\
\text { 2018; Kadenyi, 2017; Gikonyo, 2004; } \\
\text { Luvanda et al. 2016; Kiruki et al, 2016; } \\
\text { Ilyama et al, 2017; Hosier, 1985; Onekon } \\
\text { and Kipchirchir, 2016; Kitui County, } \\
\text { 2018; Njoroge, 2013; Okoko et al, } 2017\end{array}$ & $\begin{array}{l}\text { Private farmlands highly depleted off preferred hardwood species } \\
\text { Production in Kitui encroaching on protected/gazetted lands like Kitui South National Reserve } \\
\text { Preferred species being rapidly depleted leaving woodlands with softwoods only } \\
\text { Risk of losing ecosystem services and animal habitats due to deforestation/forest degradation } \\
\text { Indiscriminate charcoal production could lead to desertification } \\
\text { Felling of trees on hillsides that are water catchment and dry season grazing areas }\end{array}$ \\
\hline Kajiado & Kajiado & & 5 & $\begin{array}{l}\text { GoK, 2018; KFS, 2013; Musembi et al., } \\
\text { 2010; Muchiri, 2008; Onekon and } \\
\text { Kipchirchir, 2016 }\end{array}$ & $\begin{array}{l}\text { Land opened-up for agriculture leading to deforestation } \\
\text { Decline in charcoal production feedstock in recent years }\end{array}$ \\
\hline Central & $\begin{array}{l}\text { Nyandarua } \\
\text { Nyeri Meru } \\
\text { Tharaka } \\
\text { Nithi }\end{array}$ & $\begin{array}{l}\text { Mount Kenya, } \\
\text { Aberdare }\end{array}$ & 5 & $\begin{array}{l}\text { GoK, 2018; KFS, 2013; Osawa and } \\
\text { Muchunku, 2006; Njenga et al, 2013; } \\
\text { Mbugua, 2005; }\end{array}$ & $\begin{array}{l}\text { Charcoal production is a major cause of degradation of the two water towers (Mount Kenya and } \\
\text { Aberdare) in the central region }\end{array}$ \\
\hline Coastal & $\begin{array}{l}\text { Kilifi } \\
\text { Taita } \\
\text { Taveta } \\
\text { Kwale }\end{array}$ & $\begin{array}{l}\text { Dakacha, Shimoni } \\
\text { Forest (South } \\
\text { Coast) }\end{array}$ & 7 & $\begin{array}{l}\text { GoK, 2018; Boulkaid, 2015; Ruuska, } \\
\text { 2012; Zschauer, 2012; Muchiri, 2008; } \\
\text { Onekon and Kipchirchir, 2016; Birdlife } \\
\text { International, } 2013\end{array}$ & $\begin{array}{l}\text { Preferred tree species have been depleted } \\
\text { Illegal charcoal production going on in protected forests }\end{array}$ \\
\hline $\begin{array}{l}\text { Turkana and } \\
\text { Baringo }\end{array}$ & Baringo & Marigat & 4 & $\begin{array}{l}\text { KFS, 2013; Burrow and Mogaka 2007; } \\
\text { Wangechi, 2015; Opiyo et al, } 2015\end{array}$ & $\begin{array}{l}\text { Production promoted to control the invasive Prosopis julifora but other trees still being } \\
\text { targeted. } \\
\text { Some charcoal producers in Turkana apply salt on trees to make them dry so that they can use } \\
\text { them for charcoal production }\end{array}$ \\
\hline Nyanza & $\begin{array}{l}\text { Siaya } \\
\text { Migori }\end{array}$ & Got Ramogi & 2 & $\begin{array}{l}\text { Otuoma et al, 2011; Ngaira and } \\
\text { Omwayi, } 2012\end{array}$ & $\begin{array}{l}\text { The decline in forest density } \\
\text { Reduction on the proportion of key merchantable woody species } \\
\text { Soil erosion, reduction in water volume in rivers and loss of biodiversity are some of the effects } \\
\text { of charcoal production }\end{array}$ \\
\hline
\end{tabular}




\subsubsection{Charcoal production}

Many charcoal producers use family labour or form loose partnerships of 2-4 people, where they assist one another set up and manage each other's kiln, to minimize the cost of production (KFS, 2013; Bailis 2005). This is unpaid labour which should be valued at local labour costs for precise estimation of charcoal production. The under-valuation makes it quite difficult to estimate the cost of labour for producing one bag of charcoal, but Ndegwa (2010) gives a rough estimate of KES 50 (USD 0.6) based on local labour costs. Some large-scale producers, however, engage causal labourers to produce charcoal for them at an agreed daily wage, in which case the cost of labour is about KES 160 (USD 1.8) per bag of charcoal (KFS, 2013). In some cases, especially where the trees targeted for felling are quite large, charcoal producers are forced to hire equipment like power saws to fell and chop the stem into logs of manageable sizes. Some producers hire hoes, axes and spades to prepare the kilns. For example, Luvanda et al. (2016) reports a monthly fee of KES 1,250 (USD 12.5) for equipment and a monthly production rate of 28 bags. The equipment expenses for one bag is therefore, about KES 45 (USD 0.5). In Kakuzi, Murang'a County, the total cost of producing one bag of charcoal from residues of Eucalyptus was estimated at KES 159 (USD 2.0) inclusive of tree growing, kiln construction, harvesting of wood, operational cost, store and stock (Mugo and Gathui, 2010). Going by these estimates, we can estimate the total cost associated with production of one bag of charcoal in 2010 , in addition to that of the trees to be about KES 100-160 (USD 1.3-2.0).

Monthly charcoal production varies from place to place depending on the scale of operations of producers and the quantity of feedstock at their disposal. Nationally, Mutimba and Barasa (2005) estimated that a charcoal producer makes an average of 230 bags of charcoal annually; each weighing about $35 \mathrm{~kg}$. Studies also suggested that the average producers seemed to increase their level of production substantially, perhaps as production become more and more recognised as a business. This suggestion has been supported by other studies such as by Luvanda et al. (2016), who reported 28 bags per month and Ruuska (2012), who reported 38 bags per month. In 2013, KFS (2013) reported that an average producer in the country produced $40-60$ bags of charcoal per month which amounted to 480 720 bags per annum. 


\subsubsection{Charcoal production technology}

Charcoal is usually produced in traditional earth mound kilns (Figure 2). In this type of kiln, wood is cut into manageable sizes (around 1-2 m logs) and stacked in a semi-conical or a trapezoidal prism shape on the ground (KFS, 2013; Bailis, 2005; Mutimba and Barasa, 2005). Small twigs are inserted into the stack to fill empty spaces and support combustion when lighting. The wood is then covered with dry herbaceous vegetation (like grass) as well as soil, and then ignited (Ndegwa, 2016a; Mutimba and Barasa, 2005).
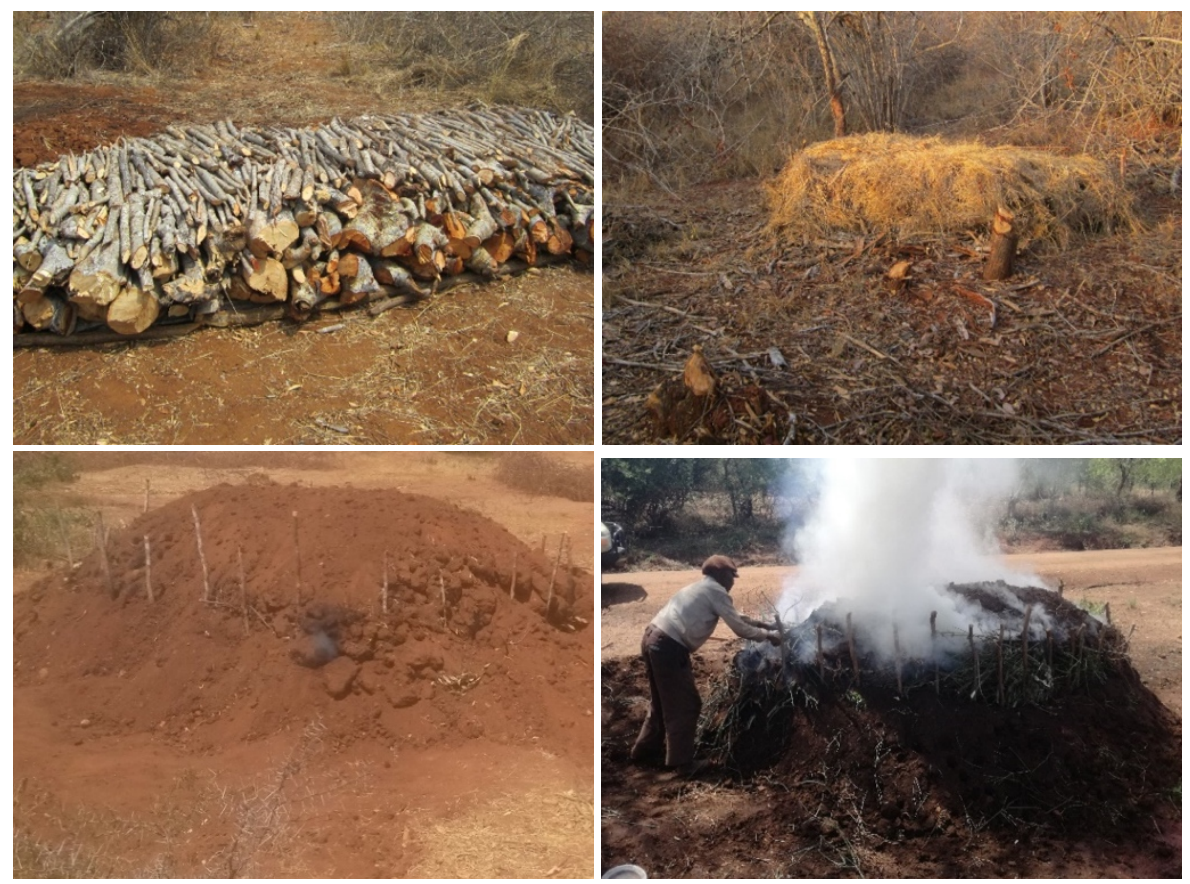

Figure 4.1: Different stages in preparation of the earth mound kiln: Top left - Stacked wood; Top right wood covered with herbaceous vegetation; Bottom left - complete kiln covered with soil; Bottom right - fired kiln. (Photos by Geoffrey Ndegwa)

Carbonization takes place under controlled conditions for 2-4 days and left to cool for 2-3 days depending on the size of the stack (Ruuska, 2012; Bailis, 2005). In total, the entire charcoal production process may take 3-10 days from stacking wood to off-loading, depending on the size of kiln.

\subsubsection{Charcoal producers' income}

The price of charcoal has been changing over time with a marginal rise from about USD 2.5 to USD5 per bag between 2000 and 2015. Mutimba and Barasa (2005) reported that the farmgate price of charcoal 
was KES 201 (USD 2.6) by 2000. Ten years later, Ndegwa (2010) reported the producer price to be KES 300 (USD 3.8) while by 2013, the average national producer price was KES 438 (USD 5.0), KFS (2013). Luvanda et al. (2016) and Ndegwa et al. (2018) reported the producer price in Kitui to be KES 400 (USD 4.0) per bag in 2016 (Figure 3). This gradual increase in the price offered to the producers may however not be significant when adjusted for inflation as cautioned by Bailis et al. (2017).

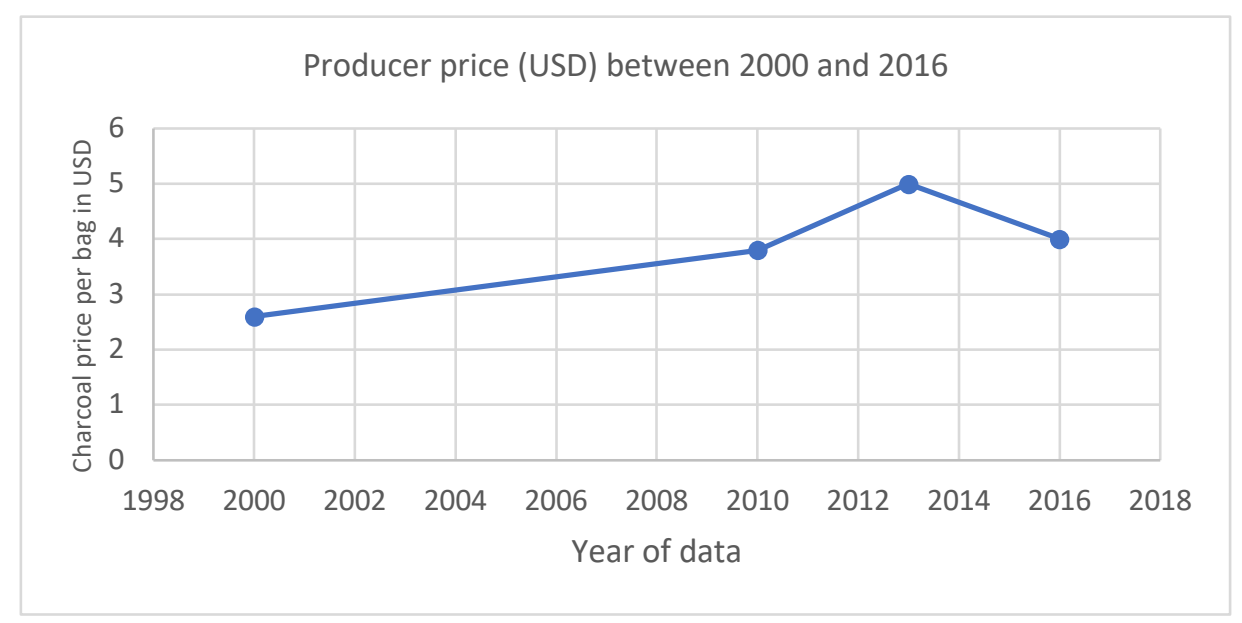

Figure 4.2: Charcoal producer price (USD) between 2000 and 2016

The average monthly income of a charcoal producer was estimated at KES 4,496 (USD 59) in the year 2000 (Mutimba and Barasa, 2005). This income had only risen marginally in a decade with 2013 estimates by Njoroge (2013) being KES 6,000 (USD 69.0) per month income for producers in Kitui while nationally KFS, (2013) estimated net average earnings to range between KES 6,000-14,000 (USD 68-160) per month per charcoal producer. For many of the charcoal-producing households, income from the product represents over 50\% of the total household income (Ndegwa et al., 2016b; Ruuska, 2012) and is thus an important source of livelihood. Charcoal producers are usually price takers from traders and transporters but belonging to a Charcoal Producers Association (CPA) is helpful as the CPAs help members negotiate better prices (Luvanda et al., 2016). All charcoal producers are required to be members of Charcoal Producers Associations (KFS, 2013) as stipulated in the Forest (Charcoal) Rules (2009); they pay a subscription fee of KES 300 (USD 3.0) per annum (Delahunty-Pike, 2012).

\subsection{Charcoal transportation}

Once charcoal is off-loaded from the kiln, it is packed into recycled 90-kg capacity polypropylene bags, with each bag carrying 28-50 kg of charcoal (Ndegwa, 2018; Ruuska, 2012; Zschauer, 2012; Mutimba and Barasa, 2005). The charcoal is either sold to transporters or wholesalers. In some cases, producers who 
are close to the major highways, especially the Nairobi-Mombasa highway, transport their charcoal to the roadside and sell to motorists where the product could fetch up to twice the price offered by transporters and wholesalers on site (KFS, 2013). Charcoal is transported using a combination of methods depending on the destination. In $2000,70 \%$ of the charcoal was transported using lorries, $20 \%$ using carts and 10\% using bicycles (Mutimba and Barasa, 2005). Human labour is mostly used to transport charcoal from the carbonization site to the nearest place where it can be loaded onto motorized transport. In Kilifi County, Ruuska (2012) reported that $44 \%$ of the charcoal was transported by lorries, $29 \%$ by canters ${ }^{3}, 16 \%$ by matatus (public passenger service vehicles) and $11 \%$ by bicycles. In 2013, KFS (2013) reported that motorcycles were fast replacing most ofnon-motorized transport means such as carts and donkeys ${ }^{4}$. This is because the motorcycles can easily manoeuvre rough terrains and can also be used to transport charcoal for slightly longer distances to the nearest market, and still remain within the law of transporting a minimum of three bags of charcoal or less without the need for a permit (KFS, 2013). Mutimba and Barasa (2005) also reported that $67.5 \%$ of the transporters owned their means of transport while $32.5 \%$ hired means or were employed as drivers.

\subsubsection{Charcoal movement licensing}

Transportation of charcoal requires a transport permit (liyama et al, 2013; KFS, 2013; Owen, 2013; wa Gathui et al., 2012). The permit is either issued by the KFS County Ecosystem Coordinator or the local KFS officers after payment of KES 20 (USD 0.2) per bag (Owen, 2013a; KFS, 2013) although permit fees mostly rounds off to either KES 1,000 (USD 10) or 2,000 (USD 20) based on the capacity of the means of transport to avoid actual verification. There is, however, lack of clarity on who is responsible for issuance of the permit, which sometimes makes the process long and cumbersome (Owen, 2013).

The business of charcoal transportation is one segment of the charcoal value chain that is riddled with corruption. The bribes paid by charcoal transporters are generally estimated to range between $20 \%$ to 30\% of the final retail price (Ndegwa, 2010; FAO, 2017). Bailis (2005) estimated that bribes paid by transporters from Narok to Nairobi at 15 checkpoints added up to KES 30,000-34,000 (USD 395-453),

\footnotetext{
${ }^{3}$ Canters is a naturalized term in the Kenya transport sector that implies trucks of with a load capacity of 3 tons, while lorries are trucks that carry 7 tons and above

4 Motorcycles have become ubiquitous in the country's transport sector after the government zero-rated all motorcycles below 250 cc in 2008 , making them very affordable. In addition, it is now easier to access affordable models from China
} 
which translated to KES 120 (USD 1.6) per bag or $26 \%$ of the final retail price. In 2013, KFS (2013) also reported that bribes paid during charcoal transportation at 16 checkpoints from Kajiado County to Nairobi ranged between KES 20,000-80,000 (USD 230-920) per trip accounting for $5-13 \%$ of the final retail price.

The illegal payments are passed over to the consumers, which increases the final market price while also reducing the transporters' profit margins. Furthermore, the transporter is required to pay KES 20 (USD 0.2) cess per bag in each of the counties the consignment passes through (Luvanda et al., 2016; KFS, 2013; Owen, 2013). In some counties like Kilifi and Mombasa, the cess is set at KES 200 (USD 2) for pickup trucks and KES 500 (USD 5) for canters to avoid the need of actual verification of the number of bags (Ruuska, 2012).

\subsubsection{Income from charcoal transportation}

A lorry can transport 150-350 bags depending on its size and the size of the bags (KFS, 2013; Ruuska, 2012; Ndegwa, 2010). On average, a lorry transports 300 bags of charcoal and could make two trips in a week (KFS, 2013; Ndegwa, 2010). This means that a single transporter can ferry 2,400 bags in a month. The final price of the charcoal is dependent on: distance between the source and destination market; expenses incurred in transportation (including bribes); supply and demand dynamics, and the season as it tends to be more expensive during the rainy season due to labour scarcity arising from peak in farm activities and the poor condition of many of the rural earth roads (KFS, 2013; Luvanda, 2016; Tesot, 2012; GoK, 2004).

The transporters' buying price depends on production cost, geographic location as well as other factors like season, producer organization ${ }^{5}$ and supply and demand dynamics (KFS, 2013; Luvanda et al., 2016). Thus, profit margins depend on the capacity of the means of transport, the destination market prices and on whether they own it or hire (KFS, 2013; Bailis, 2005). For example, Bailis (2005) reports that a transporter who owned a lorry and transported charcoal from Narok to Nairobi made a profit of $18 \%$, while those who hired only made $7 \%$.

${ }^{5}$ CPAs negotiate for better prices for members such as in Kitui County as noted earlier 
Table 4.4: Charcoal transporter costs and profit

\begin{tabular}{|l|l|l|l|l|l|l|l|l|}
\hline $\begin{array}{l}\text { Year of } \\
\text { study }\end{array}$ & $\begin{array}{l}\text { Transporter } \\
\text { buying price } \\
\text { (KES) }\end{array}$ & $\begin{array}{l}\text { Transporter } \\
\text { expenses } \\
\text { (KES) }\end{array}$ & $\begin{array}{l}\text { Transporter } \\
\text { selling price } \\
\text { (KES) }\end{array}$ & $\begin{array}{l}\text { Estimated } \\
\text { monthly } \\
\text { income } \\
\text { (KES) }\end{array}$ & $\begin{array}{l}\text { Market } \\
\text { location }\end{array}$ & $\begin{array}{l}\text { Profit } \\
\text { per bag } \\
\text { (KES) }\end{array}$ & $\begin{array}{l}\text { \% } \\
\text { profit }\end{array}$ & $\begin{array}{l}\text { Reference } \\
13\end{array}$ \\
\hline $\begin{array}{l}450 \\
\text { (Baringo) }\end{array}$ & 295 & 1000 & 189,000 & Nairobi & 255 & 25.5 & KFS, 2013 \\
\hline 2010 & 350 (Kitui) & 256 & 639 & 26,000 & Nairobi & 23 & 4 & Ndegwa 2010 \\
\hline 2000 & 260 (Kakuzi) & 50 & 350 & - & Nairobi & 40 & 11 & $\begin{array}{l}\text { Mugo and } \\
\text { Gathui, } 2010\end{array}$ \\
\hline 2000 & $\begin{array}{l}201 \\
\text { (National) }\end{array}$ & - & 335 & 11,200 & Nairobi & 134 & - & $\begin{array}{l}\text { Mutimba and } \\
\text { Barasa, } 2005\end{array}$ \\
\hline 2012 & 400 (Kilifi) & - & $600-1000$ & - & Mombasa & $200-$ & & Ruuska, 2012 \\
\hline 2000 & 108 & $188-220$ & 350 & - & Nairobi & $54-22$ & $7-18$ & Bailis 2005 \\
\hline
\end{tabular}

USD to KES Exchange rates: 2013: USD 1=KES87; 2012: USD 1=KES84; 2010: USD 1=KES80; 2000: USD 1=KES76.

The monthly income for transporters was estimated at KES 11,200 (USD 147) in 2000 (Mutimba and Barasa, 2005), KES 26,000 (USD 325) in 2010 (Ndegwa, 2010) and KES 189,000 (USD 2172) in 2013 (KFS, 2013) as shown in Table 4.4.

\subsection{Charcoal wholesaling}

Wholesalers buy charcoal from either producers or transporters and sell to retailers in bulk (usually full bags). The buying price for the wholesaler is mostly dictated by the transporters, who seek to recoup all expenses incurred during the transportation (KFS, 2013; Ndegwa, 2010). Another observation made by KFS (2013) is that the price of charcoal in Nairobi differs depending on the source, location of market and cartels in control. For instance, charcoal from Baringo fetches higher prices compared to that from Kajiado. Traders are however not at liberty to stock the cheaper charcoal as transportation is controlled by powerful cartels that determine where charcoal from each production zone is sold in the city (KFS, 2013). For example, it was reported that charcoal from Kajiado can only be sold in Pangani and its environs, that from Kitui in South B, from Tana River in Kiambu and from Baringo in Dagoretti Corner, Satellite, Kawangware and surrounding areas. As such, a transporter from Kajiado cannot be allowed by the cartels to sell his/her charcoal in South B or Kawangware where they would earn higher profits (KFS, 2013).

The charcoal wholesale price in 2000 was estimated at KES 400-450 (USD 5.3-6.6) (Bailis, 2005) rising to KES 1000-1500 (USD 11.5-17.20) in 2013 KFS (2013) an increase of 150-233\% within a period of 13 years. 
This percentage change is comparable to the producer price change over the same period, which rose from KES 108 (\$1.4) (Bailis, 2005) to KES 450 (USD 5.2) (KFS, 2013), which is a 317\% increase.

Since many charcoal wholesalers are also operating on a retail basis (selling whole sacks as well as breaking it down into smaller units like tins and buckets), many of the studies on traders have lumped them together into one category, dubbed vendors. One exception is the KFS (2013) report that was able to estimate the average monthly income of wholesalers independently at KES 48,800 (USD 561). Between 56\% (Mutimba and Barasa, 2005) and 78\% (Bailis, 2005) of the charcoal sold in Nairobi by vendors is bought from transporters with large trucks, whilst the rest is bought from individuals from nearby sources using smaller trucks and pickups.

\subsection{Retailing}

Retailers mostly buy charcoal from either wholesalers or transporters. Their most distinguishing characteristic is that they break the bag down into small units that the consumers can afford (Dalberg, 2018; Bailis, 2005). However, these smaller units have been found to cost consumers more than they would spend on a whole bag basis (Dalberg, 2018; Karekezi et al, 2008). In 2000, Mutimba and Barasa (2005) estimated that a charcoal vendor was earning an average of KES 7,500 (USD 99) per month. Ndegwa (2010), on the other hand, estimated the monthly income of retailers at KES 6,900 (USD 86) in 2010 while KFS (2013) reported it to be about KES 12,600 (USD 145) in 2013. The vendors' gross profit ranges from $15 \%$ to $52 \%$ of the final retail price as shown in Table 4.5 .

Table 4.5: Charcoal vendors expenses and profit share in a charcoal bag

\begin{tabular}{|c|c|c|c|c|c|c|c|c|c|c|c|}
\hline $\begin{array}{l}\text { Yr of } \\
\text { study }\end{array}$ & $\begin{array}{l}\text { Vendor } \\
\text { buying } \\
\text { price } \\
\text { (KES) }\end{array}$ & $\begin{array}{l}\text { Vendor } \\
\text { expenses } \\
\text { (KES) }\end{array}$ & $\begin{array}{l}\text { Vendor } \\
\text { expenses } \\
\% \text { of } \\
\text { retail } \\
\text { price }\end{array}$ & $\begin{array}{l}\text { Vendor } \\
\text { selling } \\
\text { price (KES) }\end{array}$ & $\begin{array}{l}\text { Gross } \\
\text { profit (\% } \\
\text { retail } \\
\text { price) }\end{array}$ & $\begin{array}{l}\text { Net } \\
\text { profit } \\
\text { in KES }\end{array}$ & $\begin{array}{l}\text { Net } \\
\text { profit } \\
\text { (\% of } \\
\text { retail } \\
\text { price) }\end{array}$ & $\begin{array}{l}\text { Market } \\
\text { location }\end{array}$ & $\begin{array}{l}\text { Estimated } \\
\text { mthly (KES) }\end{array}$ & $\begin{array}{l}\text { Bags } \\
\text { sold } \\
\text { per } \\
\text { mth }\end{array}$ & Ref \\
\hline 2000 & 350 & 53 & 11 & 470 & 26 & 67 & 14) & Nairobi & 3,350 & 50 & $\begin{array}{l}\text { Bailis, } \\
2005\end{array}$ \\
\hline 2000 & 335 & nd & nd & 700 & 52 & - & - & Nairobi & 11,200 & 7,503 & $\begin{array}{l}\text { Mutimba } \\
\text { and } \\
\text { Barasa, } \\
2005\end{array}$ \\
\hline 2010 & 639 & 50 & 6 & 779 & 18 & 90 & 12 & Nairobi & 6,928 & 80 & $\begin{array}{l}\text { Ndegwa, } \\
2010\end{array}$ \\
\hline 2011 & 591 & nd & nd & 688 & 15 & & & Kakamega & & $\begin{array}{l}\text { Not } \\
\text { given }\end{array}$ & $\begin{array}{l}\text { Wambua, } \\
2011\end{array}$ \\
\hline 2013 & 1,400 & nd & nd & 1,949 & 28 & & & Nairobi & 16,470 & 30 & KFS, 2013 \\
\hline
\end{tabular}


USD to KES Exchange rates: 2013: USD 1=KES 87; 2012: USD 1=KES 84; 2011: USD 1=KES 89; 2010: USD 1=KES 80; 2000: USD 1=KES 76.

At a retail price of KES 470 (USD 6.2) per bag (when it was already broken down into smaller units), Bailis, 2005 estimated the expenses and net profit of the vendor to be KES 53 (USD 0.7) and KES 67 (USD 0.9 ) respectively, which is $11 \%$ and $14 \%$ of the final retail price, respectively. In 2010 , Ndegwa (2010) estimated vendor expenses and net profit to be $6 \%$ and $12 \%$, respectively, of the final charcoal retail price in Nairobi.

\subsection{Charcoal consumption}

As reported by MoE (2002), charcoal is used by $82 \%$ of urban households and $34 \%$ of rural households. The per capita consumption in rural areas is, however, higher $(156 \mathrm{~kg})$ than that of urban areas (152 $\mathrm{kg}$ per annum). In 1999, Nyang (1999) reported that the average monthly consumption of charcoal was higher ( $52 \mathrm{~kg}$ ) for urban households using purchased charcoal than for those using self-produced charcoal (25 kg). Indeed, Hosier (1985) reported that there is a direct relationship between the amount of woodfuel consumed by a household and the amount of time required to collect it. In this case, producing charcoal for personal use in urban areas has a higher opportunity cost due to low access to wood, and is also quite laborious compared to buying, thus the low consumption level among producers. In rural areas, there was a slight difference between households using purchased charcoal (39 kg per month) and those using self-produced charcoal (33 kg per month) (Nyang, 1999).

Several attributes make charcoal the fuel of choice in urban areas compared to firewood. These attributes include; i) less or no smoke, hence can comfortably be used indoors; ii) higher calorific value per unit weight of wood; iii) easier and less expensive to transport over long distances (IEA, 2015; Ndegwa, 2010; Mbugua, 2005). In addition, the charcoal market system is also well developed - from production, transportation and trade (Ndegwa 2010) - which ensures it is readily accessible to all who need it, especially in urban areas (Mbugua, 2005). Indeed, Dalberg (2018) reports that charcoal can be accessed from between 50-150 m by many urban households. 


\subsubsection{Household charcoal consumption and budget}

For a long time, charcoal was the cheapest cooking fuel in urban areas regardless of income levels (IEA, 2015; Ndegwa, 2011; Hosier, 1985). For example, the cost of cooking with charcoal in the year 2000 was KES 12,000 (USD 150) per household per annum compared to KES 31,760 (USD 397) for LPG and KES 59,200 (USD 740) for electricity (Ndegwa, 2011). Moreover, charcoal is normally sold in small units (tins, plastic bags or buckets) which makes it affordable for the urban poor, in the short term (Dalberg, 2018; IEA, 2015; Ruuska, 2012; Karekezi et al., 2008). However, recent studies have shown that kerosene is much cheaper than charcoal, especially where charcoal is bought in small portions like tins and buckets (Dalberg, 2018; KFS, 2013; Bailis, 2005). Indeed, Bailis (2005) reports that the cost of charcoal increases by $20-25 \%$ when it is bought in smaller units. In their study, wa Gathui and Ngugi (2010) reported that by 2010, Kisumu residents also stated that cooking with charcoal had become quite expensive compared to cooking with firewood or kerosene.

Although majority of the urban charcoal users buy in small units, Gikonyo (2004) reported that more (about $90 \%$ ) rural charcoal users in Kitui buy charcoal in bulk (whole bags) compared to $10 \%$ who buy in tins. Nyang (1999) reports three main findings that may have influenced this observation: charcoal is cheaper in rural areas (KES 4.0 per kg) compared to urban areas (KES 5.1 per $\mathrm{kg}$ ); the distance travelled by rural households to buy charcoal being over three times that covered by urban dwellers $(6.2 \mathrm{~km}$ compared to $1.9 \mathrm{~km}$ ); consumers of charcoal in the rural areas usually being the well-off who can afford to buy in bulk while majority of those in the urban areas are the poor and middle-income households. Moreover, high-income urban households also use LPG and electricity together with charcoal (Mwangi, 2013).

Charcoal has an inelastic demand to income in urban areas. IPPRA (2010) also concurs with this observation, adding that unlike other solid biomass fuels like crop residues and firewood which get substituted with cleaner fuels like charcoal and LPG, households don't stop using charcoal even with an increase in the level of income. However, charcoal and other cleaner fuels like LPG have an elastic demand to price, meaning that with increase in charcoal or LPG price, households tend to switch to other cheaper options like kerosene and vice versa (Mwangi, 2013; Ruuska, 2012; KIPPRA, 2010; Nyang, 1999; GoK, 1997). 
The price of charcoal has been increasing gradually over the years with Nyang (1999) reporting prices to be KES 4-5 (USD 0.08-0.10) ${ }^{6}$ per kg in 1995 and KFS (2013) reporting KES 56 (USD 0.64) per kg in 2013. This indicates that the price of charcoal increased six-fold in a span of 14 years. Siemens (2017) also reports that the price of a 4-kg pack of charcoal has progressively increased from KES 67 (USD 0.77) ${ }^{7}$ in January 2013 to KES 82 (USD 0.79) ${ }^{8}$ in June 2017. However, Bailis et al. (2017) caution that if the price is inflation-adjusted, then it registers a marginal increase in the price over this period.

Energy consumes a substantial part of household budget, especially for very low-income group which Siemens (2017) reported could spend up to $43 \%$ of their income on energy. Wambua (2011) in a study in Kakamega County observed that the absolute household expenditure on energy increases with income while the proportion (percentage relative to income) of money spent on energy reduces with increase in income (Table 4.6).

Table 4.6: Households energy expenditure based on income quartiles

\begin{tabular}{|l|l|l|l|l|l|}
\hline Household characteristics & Ultra-poor & Poor & Non-poor & Well-off & Average \\
\hline HH size & 6.4 & 5.8 & 5 & 4.5 & 5.5 \\
\hline Annual HH expenditure (KES `000) & 76.7 & 111.8 & 144.0 & 219.8 & 130.8 \\
\hline HH annual energy budget (KES `000) & 5.2 & 7.5 & 8.5 & 13.5 & 7.7 \\
\hline HH energy share of budget (\%) & 8.0 & 6.8 & 6.0 & 6.1 & 6.9 \\
\hline
\end{tabular}

Source: Wambua, 2011

\subsubsection{Access to alternative energy sources}

Apart from woodfuel, there are other fuels available in the Kenyan energy market. These include kerosene, LPG, biogas, electricity and bioethanol (Dalberg, 2018; KIPPRA, 2010). Kerosene is considered the cheapest fuel in the country and is indeed the primary fuel for $70-80 \%$ of the poor slum population in Nairobi (Dalberg, 2018; Bizzarri, 2010). LPG is considered too expensive for majority of Kenyans because of the high cost of the cylinder, burners and refilling the gas (Dalberg, 2018; Bizzarri, 2010; UNEP, 2006). Electricity adoption has always been hampered by low penetration rate and high cost of connection to the national grid, as well as high consumer tariffs (Nyang, 1999). Finally, cooking with bioethanol would be relatively cheaper than most fuels in the market, apart from kerosene, if it was put

\footnotetext{
${ }^{6} \ln 1995, \$ 1=$ KES 51

7 In 2013, \$1= KES 87

8 In 2017, US\$1= KES 103
} 
under a favourable tax regime like other fuels (Dalberg, 2018). Briquettes are another source of biomass energy used for cooking and heating and saved $30 \%$ and $70 \%$ of income spent on cooking energy, depending on whether the households produced or purchased them (Njenga et al., 2013b). They were made by women and youth groups mainly located in low-income urban settlements using charcoal dust collected from charcoal trading sites. The briquettes burn cleaner and more evenly than firewood and charcoal depending on the raw materials used (Njenga et al., 2013c). Several factors influence the choice of a household's energy. They include:

- Level of income: with increase in level of income, households switch from lower quality fuels like firewood and crop residue to cleaner fuels like LPG and charcoal (Mwangi, 2013; KIPPRA, 2010; GoK, 1997). The vice versa is also true if the household income situation deteriorates.

- Household size: as household size increases, energy demand rises, and households may switch to lower quality and cheaper energy sources to meet the overall demand at the least cost (Wambua, 2011; KIPPRA, 2010; GoK, 1997).

- Cost of alternatives: The cost of cooking technology/options and fuel is a key determinant if a household adopts an alternative energy source or not (KIPPRA, 2010; PISCE, 2010). For example, since the initial cost of investment in the LPG cylinder and cooker is so high, acting as a barrier poor potential user (Dalberg, 2018; Mwangi, 2013; Karekezi et al., 2008). Moreover, Kariuki and Mutinda (2017) reported that the higher the cost of an improved cookstove, the lower its penetration as many people would not afford it. Boulkaid (2015) further affirms that the cost of many modern fuels like LPG is so high compared to solid biomass fuels that many rural households in Nyeri are forced to stick to the latter.

- Accessibility: Households adopt energy sources they can easily access when and where they need them. For example, one of the reasons kerosene and charcoal have high usage in Nairobi is because they are easily accessible to the population. Dalberg (2018) reports that there are over 1,500 kerosene dispensing points in Nairobi, while most people live within 50-150 m from a charcoal vendor. For the same reason, Mwangi (2013) reported that in Mukaro, Nyeri County, LPG was not readily available in the shopping centres and most households had to travel to town to access it, hence few people adopted it. Zschauer (2012) also attributed the lower rate of adoption of energysaving charcoal stoves in Taita Taveta County was because they were not readily available in the local markets.

- Education level: the level of education of the household head has been found to be directly related to adoption of cleaner energy resources (Mwangi, 2013; Wambua, 2011; KIPPRA, 2010). More 
educated household heads easily understand the problems associated with use of low-quality fuels and thus easily switch to cleaner fuels when the situation allows (Onekon and Kipchirchir, 2016; KIPPRA, 2010). Higher education is also associated with better chances of accessing better employment opportunities, and with the income, such household heads can afford the more expensive energy alternatives (Wambua, 2011).

\section{Charcoal-Related Sustainability Issues}

\subsection{Deforestation and forest degradation}

Charcoal production has been blamed for rampant deforestation, especially in forested lands close to major urban centres (UNEP, 2006; Mbugua, 2005). Onekon and Kipchirchir (2016) estimated that production of one bag of charcoal depletes 0.35 ha of forest cover while KFS (2013) estimates that production of one tonne of charcoal using the highly inefficient earth mound kilns leads to loss of 0.1 ha of forest cover. Based on the 0.35 ha depletion assumption, Onekon and Kipchirchir's (2016) estimates that charcoal consumption in Nairobi alone leads to loss of 15,175 ha of forest cover annually. Since Nairobi accounts for $10 \%$ of charcoal consumption in the country (KFS, 2013) this means that charcoal production for the entire country leads to depletion of 151,750 ha of forest cover annually. This estimate is about 10 times that reported by liyama et al. (2013) of 871,712 ha and over three times that reported by UNEP (2006) of 50,000 ha. These are huge discrepancies and more research is required if the real contribution of charcoal to deforestation and forest degradation are to be known and appropriate mitigation measures instituted.

Clearing vegetation for charcoal production has several negative impacts to the ecosystems and the environment. Some of the impacts are: loss of biodiversity; loss of animal habitat; loss of ecosystem services like food, pasture, shade, climate modulation etc; land degradation through exposure to agents of erosion, and; GHG emissions that leads to global warming and climate change (Kadenyi, 2017; Sola et al, 2017; Wanjala et al., 2015; Ngaira and Omwayi, 2012; Tesot, 2012; Zschauer, 2012; Mugo and Gathui, 2010; wa Gathui and Ngugi, 2010; Bailis, 2009). Vegetation clearance for charcoal production can be 
through clear felling where all the trees are felled regardless of species or size, and; selective logging where only trees from preferred species and size are felled (Ndegwa et al., 2018). but both approaches are detrimental to ecosystem health.

Clear felling is mostly practised where forest land is being opened up for agricultural activities, especially in Narok and Kajiado areas (Kipsisei, 2011; Bailis, 2005; Mutimba and Barasa, 2005). Unless the agricultural land is left fallow after several years of farming, and trees allowed to regenerate, clear felling usually leads to permanent deforestation and land use change (Ndegwa et al., 2018; FAO, 2017). Bailis (2005) reported that forest loss driven by agricultural expansion and charcoal production has led to total loss of vegetation cover in the high potential uplands of Narok and a reduction in vegetative cover in low potential shrubland and woody savannah areas. Ndegwa et al., 2018; FAO, 2017).

The impact of selective logging depends on the amount of wood harvested, which is commensurate with the number and size of preferred tree species available in an area (Ndegwa et al., 2016a). Selective logging for charcoal, however, leads to forest degradation (Kiruki et al, 2016; Ndegwa et al., 2016a) as the remnant forest or woodland has lower species diversity and evenness (FAO, 2017; Ndegwa et al., 2016a).

The residual forest is also predominantly composed of low-value softwood species and small saplings that are not suitable for charcoal production (Ndegwa et al., 2018; Otuoma et al., 2011; Mugo and Gathui, 2010). This change in composition could impair ecosystem functions, resilience and productivity (liyama et al., 2014). Ndegwa (2018) estimated that a dry woodland in Kitui County degraded through selective logging for charcoal production would take $25-31$ years to recover when no biomass is harvested.

Deforestation and forest degradation are exacerbated by poor natural regeneration in the dry lands which is hampered by harsh climatic conditions and exposure to browsing livestock (Ndegwa et al., 2016a; Kadenyi, 2017; Tesot, 2012; Muchiri, 2008). In addition, many residents of ASALs in Kenya do not have the culture of planting trees for woodfuel in their farmlands, but rather rely on naturally regenerated trees (Luvanda et al, 2016; Kadenyi, 2017; Ndegwa 2010; Mutimba and Barasa, 2005). For 
these reasons, if wood harvesting is not properly managed, charcoal production could essentially lead to desertification in the ASALs (Kadenyi, 2017; Ngaira and Omwayi, 2012).

Other constraints to production of sustainable woodfuels in farmlands, including charcoal, are: low adoption of agroforestry practices such as woodlots due to competing land uses; unfavourable weather conditions; insecure land tenure; lack of awareness on forest restoration; low availability of fast-growing tree species for woodfuel; unsatisfactory economic turnover; low rates of return and the time factor in investing in trees for woodfuel (Luvanda et al, 2016; MENR, 2013b; Delahunty-Pike, 2012; wa Gathui and Ngugi, 2010).

\subsection{Climate change, GHG emissions and health outcomes}

Kenya is a party to the UN Framework Convention on Climate Change, which commits to avoidance of any increase in GHGs into the atmosphere (UNEP, 2006). However, use and production of biomass fuels in the country leads to emission of approximately $35 \mathrm{MT} \mathrm{CO}_{2}$ eq into the atmosphere which is about 30$40 \%$ of the country's total GHG emission (Dalberg, 2018). Even though wood is considered a renewable resource when it is sustainably harvested, inefficient charcoal production and consumption leads to emissions of GHG into the atmosphere (FAO, 2017). The gases include, $\mathrm{CO}_{2}, \mathrm{CO}, \mathrm{N}_{2} \mathrm{O}, \mathrm{NOx}, \mathrm{CH}_{4}, \mathrm{NMHCs}$ and PMs, and have a range of negative impacts on human health and the environment (UNEP, 2006). GHG emissions in the charcoal value chain occur during wood harvesting, wood carbonization, charcoal and wood transportation, and charcoal consumption.

FAO (2017) reports that 1.4-4.4 $\mathrm{kg}$ of $\mathrm{CO}_{2} \mathrm{e}$ (global warming potential \{GWP\}) per MJ are emitted in the charcoal value chain. On average, $29-61 \%$ of these emissions occur at the wood harvesting stage, 28 $61 \%$ at the carbonization stage and $9-18 \%$ at the consumption stage (FAO, 2017). Emissions during transportation and distribution are minimal. Due to use of inefficient carbonization and combustion technologies, charcoal has 5-10 times the global warming impact of firewood and is roughly five times worse than many fossil fuels (Bailis, et al., no date). 
FAO (2017) estimated a GHG maximum emission value of 5.7-9 $\mathrm{kgCO}_{2} \mathrm{eq}^{9}$ per $\mathrm{kg}$ of charcoal produced from very unsustainable and inefficient processes including forest degradation and deforestation. Based on this emission rate, the GHG emissions associated with production of charcoal (based on 2.5 million tonnes consumption) in Kenya is about $16.8 \mathrm{kgCO}_{2} \mathrm{e}$. This figure is comparable to the Njenga et al. (2013) estimate that GHG emissions from the Kenyan charcoal sector ranges from 14.4 to 21.6 million tonnes per annum. Adopting efficient carbonization kilns can reduce the $\mathrm{GHG}$ emissions by 4,541 $\mathrm{g} \mathrm{CO}_{2} \mathrm{e}$ per $\mathrm{kg}$ of charcoal produced (an 80\% reduction) for a 100-year global warming potential (GWP) (FAO, 2017). Thus, GHG emissions can be reduced by $86 \%$ in the charcoal value chain through technological interventions in sustainable wood production, use of alternative sources of biomass energy, briquetting tree and crop wastes, improved kilns, cogeneration of charcoal and electricity, reducing fossil fuel in transportation and use of improved cook stoves (FAO, 2017). For instance, use of Acacia mearnsii plantation that has capacity to regrow integrated with improved kilns and briquette production from the charcoal dust reduces GWP by $75 \%$ compared to naturally growing woodlands combined with low efficient kilns and disposal of charcoal dust (Njenga et al., 2014).

At the consumption stage, shift from traditional to improved stoves could reduce GHG emissions by $63 \%$ (FAO, 2017). The use of improved cook stoves (ICS) has the potential to reduce household charcoal consumption by up to $50 \%$, and with it the wood-for-charcoal demand which leads to a reduction in GHG emissions (Boulkaid, 2015; Ndegwa, 2010; Mugo and Gathui, 2010). For example, Njogu and Kungu (2015) reported that adopting the Kenya Ceramic Jiko (KCJ), an improved metallic cookstove with a ceramic liner, led to a $42 \%$ reduction in charcoal consumption and savings of around $600 \mathrm{~kg}$ of charcoal per household per annum. This demonstrates the huge potential of improved cookstoves in reduction of the quantity of charcoal consumed and consequently, the wood demand for carbonization. This would in turn lead to reduced GHG throughout the entire charcoal value chain.

The GHG emitted during charcoal production and use poses a considerable health risk to the people under exposure (FAO, 2017). The impact may range from simple respiratory infections to serious chronic illnesses like asthma, emphysema bronchitis and cancer (Dalberg, 2018; UNEP, 2006). Studies indicate

\footnotetext{
${ }^{9}$ Estimate at 20-year global warming potential
} 
that households using unimproved charcoal stoves are typically exposed to particulate matter $\left(\mathrm{PM}_{10}\right)$ concentrations of about 500 micrograms per $\mathrm{m}^{3}$, while those using firewood in open fires have $\mathrm{PM}_{10}$ concentrations of more than 3,000 micrograms per $\mathrm{m}^{3}$ (Bailis et al., 2004). Similar work by Njenga et al., (2017) found indoor concentration of fine particulate matter $\left(\mathrm{PM}_{2.5}\right)$ from cooking with firewood to be over 100 times higher than charcoal (Njenga et al., 2017). $\mathrm{PM}_{2.5}$ is a common and useful indicator of the risk associated with exposure to a mixture of pollutants from diverse sources (Lim, et al., 2012) and in this respect it is safer for households to cook with charcoal. This could thus reduce the more than $50 \%$ of deaths that occur among children under five, due to pneumonia from ALRI, caused by particulate matter (soot) from household air pollution (WHO, 2016).

Dalberg (2018) reports that about 8-10\% of early deaths in Kenya are as a result of indoor air pollution from charcoal and wood emissions while cooking. Moreover, health complications resulting from indoor air pollution exacerbates poverty among the poor through reduced labour productivity and exerts pressure on their meagre income resources while seeking treatment (UNEP, 2006). However, there are consequences related to wood wastage in converting firewood to charcoal in traditional earth mound kilns. For instance, a kiln with $14 \%$ efficiency requires $72 \%$ more feedstock to produce charcoal to a cook meal compared to cooking with firewood in the three stone fire (Njenga et al., 2017). The wood wastage could be reduced through use of more efficient kilns. Cooking with more efficient stoves can help reduce indoor air pollution as well as fuel wastage. 


\section{Gender Aspects in the Woodfuel Sector}

Gender refers to socially constructed roles and relations between men and women. These vary between cultures, ethnicity and socio-economic class (Muchiri, 2008). The gender aspect in energy access and use cannot be overlooked, since fuel sourcing is primarily regarded as a responsibility of woman with some assistance from the children (Zschauer, 2012; wa Gathui and Ngugi, 2010; Nyang, 1999). For example, Mwangi (2006) reported that in 98\% of the households in Mukaro Location, Nyeri County, fuelwood was collected by women who were assisted by children.

Generally, men control exploitation of natural resources in many African societies, Kenya included (Delahunty-Pike, 2012; Nyang, 1999). Since men set the agenda on what is to be prioritized at the national, community and household level, woodfuel being the domain of women and children has rarely received much attention (Mwangi, 2013; Muchiri, 2008; Nyang, 1999). At the household level, land ownership is bestowed to men in many cultures and therefore they control which trees can be planted and when they can be harvested (Delahunty-Pike, 2012; Zschauer, 2012; Muchiri, 2008). This domination by men does not only have a negative impact on fuel access by women, but also limits access to economic benefits from tree resources (Delahunty-Pike, 2012). Women therefore have less voice insofar as wood resources management is concerned but they are the ones who are seriously affected by energy access challenges (Muchiri, 2008).

The gender disparity is also reflected in the national energy access stage where more female-headed households rely on woodfuel as a primary fuel (GoK, 2011), with $81 \%$ using firewood compared to $68.1 \%$ for male-headed households (Muchiri, 2008). In addition, a higher percentage of male-headed households are connected to electricity than the female-headed households (Muchiri, 2008). In some cases, men are also involved in fuelwood sourcing especially when physical strength is needed to fell large trees or transport heavy loads over long distances (Delahunty-Pike, 2012; Kiefer and Busman, 2008; Nyang, 1999). This happens as it is generally accepted that women are physically weaker and cannot cope with highly physical activities (Delahunty-Pike, 2012). Apart from such circumstances, men and boys mostly engage in woodfuel activities that have economic returns like charcoal production 
(GoK, 2011). Boys may also accompany women and girls during fuelwood collection trips to provide security where the sources are considered dangerous (Kiefer and Busman, 2008).

In many high agricultural potential zones like Meru and Murang'a, most of the woodfuel is sourced onfarm from planted trees which reduces the workload for women and children and the expenditure on energy (FAO, 2017). In this case, women are mostly involved in planting and caring for the trees, but when mature they belong to the man. The men decide when and for what purpose the trees will be harvested which might create woodfuel scarcity even in cases where there is an abundance of trees (Zschauer, 2012; Mugo and Gathui, 2010; Muchiri, 2008).

There are reports that women are only allowed to use wood remnants (branches and twigs) for fuel after the tree has been harvested for timber or building poles by the men (Muchiri, 2008), even though Mwangi (2013) reported women prefer to use split wood from the main stem. In Embu County, for example, $40 \%$ of households exclusively depend on agroforestry for their fuelwood supply (Njenga et al., 2019). The authors found that these households use branches from timber trees, mainly Grevillea robusta which are pruned once every two years as a management practice to encourage growth of the trunk. This not only addresses women's workload, but also allows the fuelwood to dry well thus reducing smoke in the kitchen. This will mitigate health risks associated with indoor air pollution, hence benefitting women and children as they spend a lot of time in the kitchen.

Access to clean energy services is a step towards achieving gender equality and women empowerment in the society (GoK, 2011; Sieber, 2006). This is because fuel scarcity affects women more than men in terms of physical exhaustion due to walking long distances to collect firewood, leading to loss of productive time that would have been used to generate income or care for the family (Mwangi, 2013; Zschauer, 2012; Njenga et al., 2019;). For example, Njenga et al. (2017b) reported that, rural women in Kiambu and Embu counties lost one day in every five working days on a weekly basis collecting firewood which they have to carry on their back. The associated drudgery also has serious health implications including back, legs, hand or other injuries which could incapacitate them or drain the family resources as they seek treatment (Bizzarri, 2010: Njenga et al., 2017). Firewood collection sometimes takes place 
in isolated and dangerous places which exposes the women and girls to sexual and gender-based violence (Bizzarri, 2010; Gikonyo, 2004).

In times of absolute scarcity of woodfuel, households are forced to adopt negative coping strategies like cooking approaches that compromise their nutrition intake or use low quality or unhealthy fuels like crop residue and plastics which expose the family to poisonous fumes (FAO, 2017; Zschauer, 2012; Muchiri, 2008; UN-DESA, 2004). Some of the negative coping strategies include changing diets to less energy demanding foods; undercooking food or skipping meals to save fuel; eating raw food; and bartering food and other household assets for fuel (Sola et al, 2016; Zschauer, 2012; Bizzarri, 2010). Girls are also more involved in fuel-sourcing compared to boys, which means that they lose valuable time which could have been better invested in their academics or even in socialising (Zschauer, 2012; Bizzarri, 2010; Muchiri, 2008). This has an impact on their social development, and essentially limits future income-generating opportunities at their disposal (Sieber, 2016; Delahunty-Pike, 2012; Zschauer, 2012; GoK, 2011).

Addressing challenges in accessing energy would contribute to gender equality and improve the wellbeing of women and girls. For instance, through reduced drudgery, and time saved could be invested in self and family empowerment, education, social and economic activities. There would be reduced health risks from physical injuries from carrying heavy loads while families could cook the food types of their preference.

\section{Conclusion and Recommendations}

This working paper has given a detailed account of the status of woodfuel value chains in Kenya over the past two decades based on literature published between 1999 and 2018. Throughout the years there is consistent literature that summarizes woodfuel value chains. Here we synthesise key issues on outcomes, impacts, gaps and opportunities in order to inform future research and highlight evidencebased recommendations for sustainable woodfuel value chains in Kenya. 
Woodfuel in the form of charcoal will remain one of the most important energy sources for millions of people in Kenya and Sub-Saharan Africa in general. With increased urbanization, demand will increase even more over the coming decades. Therefore, more investment and support for sustainable sourcing, production and trade in woodfuel is crucial (MENR, 2013b).

Charcoal production and trade is a livelihood issue. The charcoal sub-sector is one of the most important sources of employment and income. Although up-to-date figures are not readily available, the sub-sector has been supporting and benefitting millions of people (Mutimba and Barasa, 2005; KFS, 2013a). Yet it does not feature highly in the national socio-economic development agenda.

Most of the charcoal, is produced in highly inefficient earth mound kilns requiring as much as 10 tonnes of wood for just one tonne of charcoal. Yet very few initiatives have been mooted, let alone rolled out to develop and scale out efficient charcoal kilns. Improving stove efficiency is quite noble and comes with important health outcomes. However, failure to reduce tree cutting by improving carbonization, will see trees continue to be cut at unnecessarily high rates, thus increasing GHG emission.

Inadequate energy access, women and girls lose productive time fetching firewood in degraded landscapes and are the ones exposed to PM which cause respiratory diseases and fatalities; skipping melas and poorly cooked food contribute to poor nutrition, especially for children, Thus it is imperative that energy access should be improved to free women for more productive engagement, as well as save lives.

\section{Charcoal consumption transcends wealth classes and the Energy Ladder Theory does not hold.}

Although charcoal is relatively cheap for low income households, it is also preferred by the wealthier for cooking (Mbugua, 2005; Ndegwa, 2010; IEA, 2015; Dalberg, 2018). Thus, there is no complete transition from traditional to cleaner energy sources but energy stacking, depending on the circumstances (income, type/quantity of meal, etc.) (Dalberg, 2018). Therefore, elimination of woodfuel will remain a fallacy for a long time. This means there is need to invest in making production and consumption more efficient, cleaner and sustainable. 
Unfortunately, the sub-sector is inadequately governed and supported, even with a market value estimated in the billions, it is beset with illegality and registers billions in revenue losses, while corruption-related activities account for as much as $30 \%$ of the final charcoal retail price. Better governance and institutional mechanisms, plus incentives to improve enforcement and compliance are urgently required if the sector is to contribute to both woodfuel value chain actors' income and the national economy. 


\section{References}

Angelsen A., Jagger P., Babigumira R., Belcher B., Hogarth N. J., Bauch S., ... \& Wunder S. (2014).

Environmental income and rural livelihoods: a global-comparative analysis. World Development, $64, \mathrm{~S} 12-\mathrm{S} 28$.

Bailis R., Wang Y., Drigo R., Ghilardi A., Masera O. (2017). Getting the numbers right: revisiting woodfuel sustainability in the developing world. Environmental Research Letters 12. DOI: doi.org/10.1088/1748-9326/aa83ed.

Bailis R. (2009). Modelling climate change mitigation from alternative methods of charcoal production in Kenya. Biomass and Bioenergy 33:1491-1502.

Bailis R. (2005). Fuel from the Savanna: The Social and Environmental Implications of the Charcoal Trade in Sub-Saharan Africa. PhD Thesis. University of California, Berkeley, USA.

Bailis R., Pennise D., Ezzati M., Kammen D.M., Kituyi E. (No date). Impacts of greenhouse gas and particulate emissions from woodfuel production and end-use in Sub-Saharan Africa. Energy and Resources Group, University of California, Berkeley, CA, USA

Bar R., Ehrensperger A. (2018). Accounting for the boundary problem at subnational level: The supplydemand balance of biomass cooking fuels in Kitui County, Kenya. Resources 7 (1). doi:10.3390/resources7010011.

Birdlife International (2013). Biodiversity Status and Trends Report for the Eastern Arc Mountains and Coastal Forests of Kenya and Tanzania Region, 2012. Birdlife International - Africa Partnership Secretariat, Nairobi.

Bizzari M. (2010). Safe access to firewood and alternative energy in Kenya: An appraisal report. Rome, World Food Program of the United Nations (WFP).

Boulkaid Y. (2015). Quantifying the Potential Impact of Improved Stoves in Nyeri County, Kenya. Master Thesis. KTH Royal Institute of Technology, Stockholm, Sweden.

Burrow E., Mogaka H. (2007). Kenya's drylands - wastelands or an undervalued national economic resource. IUCN - The World Conservation Union, Eastern Africa Regional Office, Nairobi. 
Butynski T.M., de Jong Y.A. (2016). South Western Mau Forest Reserve Game-proof Barrier Feasibility Study. Nairobi, Initiative for Sustainable Landscapes (ISLA).

Chabeda-Barthe J. (2013). Are rural women to blame for misusing wood for livelihood and household use in Burnt Forest Area, Kenya. Paper presented at the Rural History 2013 Conference at the University of Bern from 19-22 August 2013. Bern, European Rural History Organization (EURHO).

Cheboiwo J.K. (2016). Private forestry sector in Kenya: status and potential. AFF Report. Nairobi, African Forest Forum.

County Government of Kitui (2018). County fiscal strategy paper (2018/19). County Government of Kitui, County Treasury. Kitui.

Dalberg (2018). Scaling up clean cooking in urban Kenya with LPG \& Bio-ethanol: A market and policy analysis. Nairobi, Dalberg Research.

Delahunty-Pike A. (2012). Gender equity, charcoal and the value chain in western Kenya: Working brief prepared for PISCES by Practical Action Consulting. Practical Action, Nairobi, Kenya.

DFID (2002). Historical Framework: Major events that have affected inter-fuel substitution in Kenya from 1960s to Present. London, Department for International Development (DFID).

FAO (2017). The charcoal transition: Greening the charcoal value chain to mitigate climate change and improve local livelihoods. Rome, Food and Agriculture Organization of the United Nations.

wa Gathui T., Mugo F., Ngugi W., Kamau S. (2012). The Kenya Charcoal Regulations Pocketbook.

Prepared for PISCES by Practical Action Consulting. Practical Action, Nairobi, Kenya.

wa Gathui T, Ngugi W. (2010). Bioenergy and poverty in Kenya: Attitudes, actors and activities. Working paper prepared for PISCES by Practical Action Consulting. Practical Action, Nairobi, Kenya.

Gikonyo J.M. (2004). The effects of biomass energy use by rural households in a dryland environment case study of Mwingi District. Master Thesis. University of Nairobi, Kenya.

GLPGP (2013). Kenya Market Assessment. Nairobi, The Global LPG Partnership (GLPGP).

GoK (2018). A report on forest resources management and logging activities in Kenya: findings and recommendations. Ministry of Environment and Forestry, Nairobi. 
GoK and UNDP (2016). Access to clean energy in rural Kenya through innovative market-based solutions.

Nairobi, Government of the Republic of Kenya (GoK) and United Nations Development

Programme (UNDP).

GoK (2016). Sustainable Energy for All (Se4all). Kenya Action Agenda. Nairobi, Government of the Republic of Kenya.

GoK (2011). Scaling-up renewable energy program (SREP) investment plan for Kenya. Nairobi,

Government of the Republic of Kenya (GoK).

GoK (2004). Sessional paper no. 4 on energy. Nairobi, Ministry of Energy.

GoK (1997). National land degradation assessment and mapping in Kenya. Nairobi, Government of the Republic of Kenya.

Hosier R. (1985). Energy use in rural Kenya: Household demand and rural transformation. Stockholm, Beijer Institute.

IEA (2015). Situational analysis of energy industry, policy and strategy for Kenya. Nairobi, Institute of Economic Affairs (IEA).

liyama M., Neufeldt H., Njenga M., Derero A., Ndegwa G., Mukuralinda A., Dobie P., Jamnadass R., Mowo J. (2017). Conceptual Analysis: The Charcoal-Agriculture Nexus to Understand the SocioEcological Contexts Underlying Varied Sustainability Outcomes in African Landscapes. Frontiers in Environmental Science 5: 31. doi: 10.3389/fenvs.2017.00031.

liyama M., Chenevoy A., Otieno E., Kinyanjui T., Ndegwa G., Vandenabeele J., Njenga M., Johnson O. (2014). Achieving sustainable charcoal in Kenya: Harnessing the opportunities for cross-sectoral integration. Nairobi, World Agroforestry (ICRAF) and Stockholm Environment Institute (SEI). liyama M., Neufeldt H., Dobie P., Njenga M., Ndegwa G., Jamnadass R. (2014a). The potential of agroforestry in the provision of sustainable wood fuel in sub-Saharan Africa. Current Opinion in Environmental Sustainability 6, pp 138-47.

Kadenyi N. (2017). Assessment of socioeconomic importance of roadside tree planting in arid and semiarid areas: Case study at Kathome/Kawongo, Kitui County. Master Thesis. South Eastern Kenya University.

KFS (2014). Drylands forest livelihoods. Factsheet no. 2: Charcoal. The Kenya Forest Service. Nairobi. 
Karekezi S., Kimani J., Onguru O. (2008). Energy access among the urban poor in Kenya. Energy for Sustainable Development 7(4):38-48.

Kariuki J.W., Mutinda J. (2017). Assessment of the contribution firewood conservation stove in sustainable use of wood fuel energy in Embu North Sub-County, Kenya. International Journal of Scientific and Research Publications 7(11): 599-605.

Kendagor, L.K., Prevost, R.J. (2013). Energy diversity and development in Kenya: Kenya: National Defense University (NDU).

Kenya Land Alliance (2015). Land use in Kenya: The case for a national land use policy. Nairobi, Kenya Land Alliance.

Kiefer S., Bussmann R.W. (2008). Household energy demand and its challenges for forest management in the Kakamega area, Western Kenya. Ethnobotany Research \& Applications 6:363-371.

Kiruki H.M., van der Zanden M.H., Malek Z., Verburg P.H. (2016). Land cover change and woodland degradation in a charcoal-producing semi-arid area in Kenya. Land Degradation \& Development. DOI: $10.1002 / / d r .2545$.

KFS (2013). Analysis of the charcoal value chain in Kenya. A report commissioned by the Kenya Forest Service (KFS), coordinated by the National REDD+ Coordinating Office (NRCO) and carried out by Camco Advisory Services (Kenya) Limited. Nairobi, Kenya.

KFS (2017). Forest law enforcement and governance in Kenya. A paper prepared for the East African Community-led regional process in the framework of the Ministerial Declaration, Yaoundé, Cameroon, October 16, 2003 on the Africa Forest Law Enforcement and Governance (AFLEG). Nairobi, Kenya Forest Service (KFS).

Kenya National Bureau of Statistics (KNBS). (2007). Basic report on well-being in Kenya based on Kenya Integrated Household Budget Survey - 2005/06. Nairobi, Kenya National Bureau of Statistics (KNBS).

Kenya National Bureau of Statistics (KNBS). (2018). Report on well-being in Kenya based on Kenya Integrated Household Budget Survey - 2015/16. Nairobi, Kenya National Bureau of Statistics (KNBS). 
Kenya National Bureau of Statistics (KNBS). (2010). The Kenya 2009 Population and Housing Census Population Distribution by Administrative Units: Volume 2. KNBS, Nairobi, Kenya.

KIPPRA (2010). A comprehensive study and analysis on energy consumption patterns in Kenya: A synopsis of the draft final report. Nairobi, Kenya Institute for Public Policy Research and Analysis (KIPPRA).

Kipsisei G.C. (2011). Environmental degradation and social conflict in Trans Mara District, South Rift Valley of Kenya. Master Thesis. University of Nairobi, Kenya.

Lim S.S., Vos T., Flaxman A.D., Danaei G., Shibuya K., Adair-Rohani H., Ezzati, M. (2012). A comparative risk assessment of burden of disease and injury attributable to 67 risk factors and risk factor clusters in 21 regions, 1990-2010: a systematic analysis for the Global Burden of Disease Study 2010. Lancet, 380(9859), 2224-2260. http://doi.org/10.1016/S0140-6736(12)61766-8.

Luvanda A.M., Kitheka E., Oduor N., Kyalo E.M., Githiomi J. (2016). Impact and assessment of charcoal marketing system through community associations in Kitui County, Kenya. Octa Journal of Environmental Research, 4(2), 086-091.

Mbugua G. (2005). Energy sources in Kenya: Implications for forests. Wajibu 20 (2):10-11.

MENR (2015). Widening informed stakeholder engagement in REDD+: Charcoal and REDD+ in Kenya. Ministry of Environment and Natural Resources. Republic of Kenya, Nairobi.

MENR (2013b). Analysis of demand and supply of wood products in Kenya. Nairobi Ministry of Environment, Water and Natural Resources (MENR).

Ministry of Energy (MoE), Government of Kenya, (2002). Study on Kenya's Energy Demand, Supply and Policy Strategy for Households, Small Scale Industries and Service Establishments. Final Report for the Ministry of Energy. May, Kamfor Company Ltd.

Muchiri L. (2008). Gender and equity in bioenergy access and delivery in Kenya. Working paper prepared for PISCES by Practical Action Consulting. Practical Action, Nairobi, Kenya.

Mugo F., Gathui T. (2010). Biomass energy use in Kenya. A background paper prepared for the International Institute for Environment and Development (IIED) for an international ESPA workshop on biomass energy, 19-21 October 2010, Parliament House Hotel, Edinburgh. Practical Action, Nairobi, Kenya. 
Musembi F.J., Nandokha T., Njeru P., Mbure G.H., Matere S., Emongor R. (2010). Baseline study on status of biofuel technology in Kajiado and Kisii regions. Paper presented at the $12^{\text {th }}$ KARI Scientific Conference Proceedings 2010. Nairobi, Kenya Agricultural Research Institute (KARI).

Mutimba S., Barasa M. (2005). National charcoal survey: Summary report. Exploring the potential fora sustainable charcoal industry in Kenya. Nairobi: Energy for Sustainable Development Africa (ESDA).

Mwangi V.W. (2013). Energy consumption among rural households in Mukaro Location of Nyeri County, Kenya. Master Thesis. University of Nairobi, Kenya.

Ndegwa G.N. (2010). Woodfuel value chains in Kenya and Rwanda: Economic analysis of the market oriented woodfuel sector. Master Thesis. Cologne University of Applied Sciences, Germany. Ndegwa G.M., Nehren U., Anhuf D., liyama M. (2018). Estimating sustainable biomass harvesting level for charcoal production to promote degraded woodlands recovery: A case study from Mutomo District, Kenya. Land Degradation \& Development 29 (5): 1521-1529. DOI: 10.1002/Idr.2938.

Ndegwa GM. (2017). Evaluating dry woodlands degradation and on-farm tree management in Kenyan drylands. PhD Thesis. University of Passau, Germany.

Ndegwa G., Nehren U., Grüninger F., liyama M., Anhuf D. (2016a). Charcoal production through selective logging leads to degradation of dry woodlands: a case study from Mutomo District, Kenya. J Arid Land 8(4): 618-631. doi: 10.1007/s40333-016-0124-6.

Ndegwa G.M., Anhuf D., Nehren U., Ghilardi A., liyama M. (2016b). Charcoal contribution to wealth accumulation at different scales of production among the rural population of Mutomo District in Kenya. Energy for Sustainable Development 33:167-175. Doi: 10.1016/j.esd.2016.05.002

Ndegwa G., Breuer T., Hamhaber J. (2011). Woodfuels in Kenya and Rwanda: powering and driving the economy of the rural areas. Rural 21, the International Journal for Rural Development no. 2/2011. Available at: www.rural21.com.

Ndegwa J. (2011). Bioenergy market system development: comparing participatory approaches in Kenya and Sri Lanka. Working paper prepared for PISCES by Practical Action Consulting. Practical Action, Nairobi, Kenya. 
Ngaira J.K.W., Omwayi K. (2012). Climate change mitigation: Challenges of adopting the green energy option in the Lake Victoria basin. International Journal of Physical Sciences 41: 5615-5623.

Ngetich K.A., Birech R.J., Bett K.E., Ereyer B. (2009). Caught between energy demands and food needs: Dilemmas of smallholder farmers in Njoro, Kenya. Journal of Agriculture and Rural Development in the Tropics and Subtropics 110 (1): 23-28.

Njenga M., Gitau J., liyama M., Jamnadass R., Mahmoud Y., Karanja N. (2019). Innovative biomass cooking approaches for Sub-Saharan Africa. Afr. J. Food Agric. Nutr. Dev. 19(1):14066-14087

Njenga M., Karanja N., Karlsson H., Jamnadass R., liyama M., Kithinji J., Sundberg C. (2014). Additional cooking fuel supply and reduced global warming potential from recycling charcoal dust into charcoal briquette in Kenya. Journal of Cleaner Production. 81, 81-88

Njenga M., Karanja N., Munster C., liyama M., Neufeldt H., Kithinji J., Jamnadass R. (2013). Charcoal production and strategies to enhance its sustainability in Kenya. Development in Practice, 23:3, 359-371, DOI:10.1080/09614524.2013.780529.

Njenga M., Mahmoud Y., Mendum R., liyama M., Jamnadass R., Roing de Nowina K., Sundberg C., (2017), Quality of charcoal produced using micro gasification and how the new cook stove works in rural Kenya. Environ Research Letters, 12 (9).

Njenga M., Mendum R., Gitau J., liyama M., Jamnadass R., Watson C. (2017b). Trees on farms could satisfy household firewood needs, The tree farmers magazine for Africa Issue No. 33: 20-23, Better Globe Forestry Ltd, Nairobi, Kenya.

Njenga M., Yonemitsu A., Karanja N., liyama M., Kithinji J., Dubbeling M., Sundberg C., Jamnadass R. (2013b). Implications of charcoal briquette produced by local communities on livelihoods and environment in Nairobi, Kenya. International Journal of Renewable Energy Development (IJRED). 2 (1) 19-29.

Njoroge N. (2013). Influence of charcoal trade on the livelihoods of rural communities: a case of Mitamisyi Location in Kusyo District of Kitui County. Master Thesis. University of Nairobi, Kenya. Njogu P.K., Kungu J.B. (2015). Factors influencing adoption of woodfuel energy saving technologies in Nakuru County, Kenya. International Journal of Science and Research (IJSR) 4(2): 1028-1036. 
NL Agency (2010). Making charcoal production in Sub Sahara Africa sustainable. NL Agency, Utrecht, The Netherlands.

Nyang, F.O. (1999). Household energy demand and environmental management in Kenya. PhD Thesis. University of Amsterdam, The Netherlands.

Nyong'a E., Rajamani H., Carruthers A. (2018). An investigation of the environmental impact of rising household energy demand in Kenya. Paper presented at the 16th International Conference on Clean Energy (ICCE-201 8) 9-11 May 201 8, Famagusta, N. Cyprus.

Oduor N. (2012). Sustainable feedstock management for charcoal production in Kenya: Resources, initiatives and options. Working brief prepared for PISCES by Practical Action Consulting. Practical Action, Nairobi, Kenya.

Okoko A., Reinhard J., von Dach S.W., Zah R., Kiteme B., Owuor S., Ehrensperger A. (2017). The carbon footprints of alternative value chains for biomass energy for cooking in Kenya and Tanzania. Sustainable Energy Technologies and Assessments 22: 124-133.

Onekon W.A., Kipchirchir K.O. (2016). Assessing the effect of charcoal production and use on the transition to a green economy in Kenya. Tropical and Subtropical Agroecosystems, 19: 327 - 335.

Opiyo F., Wasonga O., Nyangito M., Schilling J., Munang R. (2015). Drought adaptation and coping strategies among the Turkana pastoralists of northern Kenya. Int J Disaster Risk Sci (2015) 6:295309.

Osawa B., Muchunku C. (2006). Energy conflicts in the Meru region. FWU 5: 31-41.

Otuoma J., Odera J., Bodo E., Ongugo P., Oeba V., Kamondo B. (2011). Annual allowable cut for merchantable woody species in a community managed forest in western Kenya. Forest Ecology and Management 262: 2281-2286.

Owen M. (2013). The legally compliant charcoal industry and its barriers to growth in Kenya. Nairobi, Kenya Forest Service (KFS).

Ruuska E. (2012). The significance and sustainability of charcoal production in the changing landscape of Dakatcha Woodland, SE Kenya. Master Thesis. University of Helsinki, Finland.

Sepp (No date). Analysis of charcoal value chains general considerations. Eco Consulting Group Germany. 
Sieber P. (2016). Implications of improved biofuel management for climate change: An LCA-based evaluation of biochar and charcoal in Kenyan smallholder farming. Master thesis, University of Natural Resources and Life Sciences Vienna (BOKU).

Siemens J. (2017). Exploring the feasibility of a biomass briquette enterprise with a youth cooperative in Nairobi. University Project. University of Victoria, Canada.

Sola P., Ochieng C., Yila J. et al. (2016). Links between energy access and food security in sub Saharan Africa: an exploratory review. Food Sec. (2016) 8: 635. doi:10.1007/s12571-016-0570-1.

Sola P., Cerutti P.O., Zhou W., et al. (2017). The environmental, socioeconomic, and health impacts of woodfuel value chains in Sub-Saharan Africa: a systematic map. Environ Evidence (2017) 6:4 DOI $10.1186 / \mathrm{s} 13750-017-0082-2$

Tesot A.K. (2014). Environmental implications of the charcoal business in Narok-South Sub-County, Narok County. Master Thesis. Kenyatta University, Kenya.

TRANSrisk (2017). Energy Access and Climate Change in Sub-Saharan Africa: linkages, synergies and conflicts. Sussex, UK, Transitions Pathways and Risk Analysis for Climate Change Mitigation and Adaptation Strategies.

UN-DESA (2004). Sustainable Energy Consumption in Africa. New York, United Nations Department of Economic and Social Affairs.

UNEP (2017). Improving efficiency in forestry operations and forest product processing in Kenya: A viable REDD+ policy and measure. Nairobi, United Nations Environment Programme (UNEP).

UNEP (2006). Kenya: Integrated assessment of the energy policy with focus on the transport and household energy sectors. Nairobi, United Nations Environment Programme (UNEP).

Wambua S.M. (2011). Household energy consumption and dependency on common pool forest resources: The case of Kakamega Forest, Western Kenya. PhD Thesis. Georg-August-University Göttingen, Germany.

Wangechi J. (2015, April). Charcoal burning ban opposed by residents. Reject 107:6.

Wanjala M.C. (2016). Sustainable charcoal production technologies in Kenya: The case of Kwale, Narok and Taita Taveta counties. Final report on field project activities. Kenya Forest Service, Nairobi, Kenya. 
Wanjala F., Obwoyere G., Eshiamwata G. (2015). Wood fuel utilization patterns and cooking devices efficiency analysis for Likia residents, Njoro Kenya. Journal of Natural Sciences Research 5(24): 158-173.

WHO (2016). Household air pollution and health Fact sheet N²92 (Geneva: WHO)

Zshauer K., (2012). Households energy supply and the use of fuelwood in the Taita Hills, Kenya; https://helda.helsinki.fi/bitstream/handle/10138/29517/househol.pdf?sequence=1 


\section{Appendix 1: Search terms used during the scoping study}

\section{Value-chain}

("Wood fuel" OR "Wood-fuel") AND (charcoal OR firewood) AND "value-chain" AND Kenya

("Wood fuel" OR "Wood-fuel") AND (charcoal OR firewood) AND (trade OR market) AND Kenya

("Wood fuel" OR “Wood-fuel") AND (charcoal OR firewood) AND (income OR revenue OR returns) AND Kenya

("Wood fuel" OR “Wood-fuel”) AND (charcoal OR firewood) AND (price OR cost) AND Kenya

\section{Production}

("Wood fuel" OR “Wood-fuel”) AND production AND Kenya

Charcoal AND (production OR burning) AND Kenya

Charcoal AND production AND "hot-spots" AND Kenya

Charcoal AND "hot-spots" AND Kenya

("Wood fuel" OR "Wood-fuel") And (charcoal OR firewood) AND "forest degradation" AND Kenya

("Wood fuel" OR “Wood-fuel") AND (charcoal OR firewood) AND deforestation AND Kenya

\section{Movement}

Charcoal AND (transport OR movement) AND Kenya

("Wood fuel" OR “Wood-fuel") AND (charcoal OR firewood) AND ("transport routes" OR "trade routes") AND Kenya

\section{Cross-border}

("Wood fuel" OR “Wood-fuel") AND (charcoal OR firewood) AND “cross-border" AND (transport OR movement) AND Kenya AND Tanzania

("Wood fuel" OR “Wood-fuel") AND (charcoal OR firewood) AND “cross-border" AND (transport OR movement) AND Kenya AND Uganda

("Wood fuel" OR "Wood-fuel") AND (charcoal OR firewood) AND "cross-border" AND (transport OR movement) AND Kenya AND Somali

("Wood fuel" OR "Wood-fuel") AND (charcoal OR firewood) AND "cross-border" AND trade AND Kenya AND Uganda

("Wood fuel" OR "Wood-fuel") AND (charcoal OR firewood) AND "cross-border" AND trade AND Kenya AND Tanzania

("Wood fuel" OR "Wood-fuel") AND (charcoal OR firewood) AND "cross-border" AND trade AND Kenya AND Somali

("Wood fuel" OR “Wood-fuel”) AND (charcoal OR firewood) AND border AND control AND Kenya AND Somali

("Wood fuel" OR “Wood-fuel") AND (charcoal OR firewood) AND border AND control AND Kenya AND Tanzania 
("Wood fuel" OR “Wood-fuel”) AND (charcoal OR firewood) AND border AND control AND Kenya AND Uganda

("Wood fuel" OR “Wood-fuel”) AND (charcoal OR firewood) AND (conflict OR war) AND Somali

\section{Sites}

("Wood fuel" OR "Wood-fuel") AND (charcoal OR firewood) AND production AND Kitui

("Wood fuel" OR “Wood-fuel”) AND (charcoal OR firewood) AND production AND Garissa

("Wood fuel" OR “Wood-fuel") AND (charcoal OR firewood) AND (trade OR market) AND Nairobi

("Wood fuel" OR "Wood-fuel") AND (charcoal OR firewood) AND (trade OR market) AND Mombasa

("Wood fuel" OR “Wood-fuel”) AND (charcoal OR firewood) AND (trade OR market) AND Garissa

("Wood fuel" OR “Wood-fuel") AND (charcoal OR firewood) AND (trade OR market) AND Kisumu

\section{Gender}

("Wood fuel" OR "Wood-fuel") AND (charcoal OR firewood) AND gender AND Kenya

("Wood fuel" OR “Wood-fuel") AND (charcoal OR firewood) AND women AND Kenya. 


\section{Working Paper Series}

\section{$\underline{2018}$}

290. Indonesia Rural Economic Development Series. Growing plants on a barren hill: local knowledge as part of land restoration in Sumba Timur, Indonesia. http://dx.doi.org/10.5716/WP18030.PDF

291. Assessing the Downstream Socioeconomic Impacts of Agroforestry in Kenya http://dx.doi.org/10.5716/WP18033.PDF

\section{$\underline{2019}$}

292. Los árboles fuera del bosque en la NAMA forestal de Colombia. Elementos conceptuales para su contabilización. http://dx.doi.org/10.5716/WP19002.PDF

293. Gender and Adaptation: An Analysis of Poverty and Vulnerability in Yunnan, China. http://dx.doi.org/10.5716/WP19004.PDF

294. Tree Cover on Agricultural Land in the Asia Pacific Region http://dx.doi.org/10.5716/WP19005.PDF

295 What do we really know about the impacts of improved grain legumes and dryland cereals? A critical review of 18 impact studies. http://dx.doi.org/10.5716/WP19006.PDF

296. Breeders' views on the production of new and orphan crops in Africa: a survey of constraints and opportunities http://dx.doi.org/10.5716/WP19007.PDF

297. Biomass Resources in Rhino Camp and Imvepi Refugee Settlements and the Buffer Zone around these Settlements in West Nile, Uganda http://dx.doi.org/10.5716/WP19031.PDF

298. Option for restocking woody biomass in refugee-hosting areas: Perspectives from communities in Rhino Camp and Imvepi Settlements, Uganda. http://dx.doi.org/10.5716/WP19032.PDF

299. Restoring ecosystems in refugee settlements using tree-based systems: The case of Rhino Camp and Imvepi Settlements in Uganda. http://dx.doi.org/10.5716/WP19033.PDF

300. A theory-based evaluation of the Agroforestry Food Security Programme, Phase II in Malawi (AFSPII): Lessons for Scaling Up Complex Agronomic and Natural Resource Management Practices Developed and Tested in Research Settings. http://dx.doi.org/10.5716/WP19036.PDF

301. Fuentes semilleras y especies agroforestales de los bosques secos tropicales del norte del Perú: estado actual y prioridades futuras. (Spanish) http://dx.doi.org/10.5716/WP19057.PDF

302. Seed sources and agroforestry species of tropical dry forests of northern Peru: current status and future priorities. (English) http://dx.doi.org/10.5716/WP19058.PDF

303. Turmeric Production under Shade Management and Fertilization in Degraded Landscapes of Sumba Timur. http://dx.doi.org/10.5716/WP19066.PDF

\section{$\underline{2020}$}

304. From "Tree-planting" to "Tree-growing": Rethinking Ecosystem Restoration Through Trees. http://dx.doi.org/10.5716/WP2020001.PDF

305. Agroforestry species of Peru: Reference list and contribution to prioritization for the conservation of agroforestry genetic resources. http://dx.doi.org/10.5716/WP20013.PDF 
306. An exploratory analysis of cost-benefit analysis of landscape restoration. http://dx.doi.org/10.5716/WP20014.PDF 
World Agroforestry (ICRAF) is a centre of scientific and development excellence that harnesses the benefits of trees for people and the environment. Leveraging the world's largest repository of agroforestry science and information, we develop knowledge practices, from farmers' fields to the global sphere, to ensure food security and environmental sustainability.

ICRAF is the only institution that does globally significant agroforestry research in and for all of the developing tropics. Knowledge produced by ICRAF enables governments, development agencies and farmers to utilize the power of trees to make farming and livelihoods more environmentally, socially and economically sustainable at multiple scales.

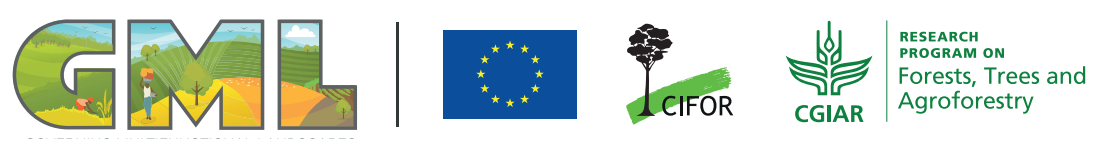

\section{Acknowledgements}

This study has been conducted with the generous support of the European Union through the Governing Multifunctional Landscapes in Sub-Saharan Africa (GML) project, implemented by the Center for International Forestry Research (CIFOR) in partnership with World Agroforestry (ICRAF), the Deutsche Gesellschaft für Internationale Zusammenarbeit (GIZ), the Forest and Farm Facility (FFF), the Food and Agriculture Organization of the United Nations (FAO), and national and local organizations. We are also grateful for the support received from the CGIAR Programme on Forests, Trees and Agroforestry (FTA).

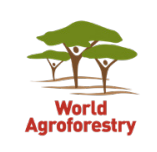

United Nations Avenue, Gigiri • PO Box 30677 • Nairobi, $00100 \cdot$ Kenya

Telephone: +254207224000 or via USA +16508336645

Fax: +254207224001 or via USA +1 6508336646

Email: worldagroforestry@cgiar.org • www.worldagroforestry.org 